\title{
STUDIUM KERAMIKY VRCHOLNÉHO A POZDNÍHO STŘEDOVĚKU V ČECHÁCH - TÉMATA, METODY, PŘÍSTUPY
}

\section{LADISLAV ČAPEK}

\begin{abstract}
Abstrakt: Cílem přispěvku je zhodnotit více než 60letý vývoj systematického studia keramiky vrcholného a pozdního středověku v Čechách a predstavit základni témata a metody, které se rozvíjely v souladu s formující se disciplínou archeologie mladšiho středověku. Na středověké keramice jako nejrozšiřrenějším artefaktu a různých přistupech k jejímu studiu můžeme dobře ilustrovat vývoj české archeologie mladšiho středověku, který ovlivňovaly soudobá archeologická paradigmata a v počátcích studia i ideologické koncepty spojené s marxistickou historiografí. Vývoj studia vrcholně a pozdně středověké keramiky můžeme rozčlenit do pěti hlavnich období-starožitnické období, počátky studia - typologická fáze, další rozvoj typologického studia zaměreného na regionálni sekvence keramiky až po současnou pokračujicí kontextuální fázi s důrazem na komplexnějši pojeti studia a hlubši sociálně-ekonomické otázky. Podobný trend ve vývoji studia středověké keramiky můžeme zaznamenat i u západoevropských zemí. Vývoj je v předloženém přispěvku demonstrován rovněž na základě kritického hodnocení publikovaných studií o vrcholně a pozdně středověké keramice v prednich domácích periodikách - Archeologické rozhledy a Archaeologia historica.
\end{abstract}

Klíčová slova: vrcholně a pozdně středověká keramika - Čechy - dějiny bádání - paradigmata - teorie metody výzkumu.

\section{The study of pottery of the high and late Middle Ages in Bohemia-subjects, methods, approaches}

\begin{abstract}
This contribution charts the sixty years of the systematic study of pottery of the high and late Middle Ages in Bohemia, and introduces the basic subjects and methods developed along with the progress of archaeology of the late Middle Ages. Medieval pottery involving the most widespread artefacts and various approaches to their study illustrate the development of Czech archaeology of the late Middle Ages influenced by contemporaneous archaeological paradigms, and initially also by ideological concepts associated with Marxist historiography. The history of the study of pottery of the high and late Middle Ages can be divided into five main areas: the antiquarian period and the beginnings of study; the typological phase; further development of the typological study focused on regional sequences of pottery, and the present, ongoing contextual phase with emphasis on a more comprehensive approach to the study and more profound socio-economic issues. A similar trend in the development of the study of medieval pottery can be observed in west-European countries. In the paper the development is also demonstrated on the basis of the critical assessment of studies dedicated to pottery of the high and late Middle Ages published in two leading specialist Czech periodicals, Archeologické rozhledy and Archaeologia historica.
\end{abstract}

Key words: pottery of the high and late Middle Ages - Bohemia - history of research-paradigms - theories research methods.

\section{Úvod}

V domácí archeologii postrádáme bilanční a diskusní práce, které by kriticky hodnotily vývoj výzkumu v různých oblastech studia středověké archeologie ve vztahu k soudobým teoretickým otázkám a paradigmatům a sledovaly rovněž proměny metodických přístupů, které se často vyvíjely na základě inspirující spolupráce, pod vlivem zahraničních studií či kontaktů archeologie s dalšími vědeckými disciplínami.

Takové práce chybí i v př́ípadě studia keramiky mladšího a pozdního středověku v Čechách, na jejímž př́íkladu můžeme dobře sledovat postupný vývoj rozmanitých témat, metod a př́istupů, ve kterých můžeme zaznamenat, at' již přímé, nebo nepřímé ovlivňování tehdejšími paradigmaty a v počátcích studia i ovlivnění ideologicky podbarvenými koncepty. Pro vznik a vývoj archeologie mladšího středověku zabývající se středověkou keramikou byl nepochybně velmi inspirující vztah k jiným prŕbuzným disciplínám - historii, etnografii, dějinám umění a později i k prŕrodovědným oborům. Formování výzkumu středověké keramiky ovlivňovaly také významné 
osobnosti, které svými př́spěvky otevíraly diskuse, zprostředkovávaly informace z mnohdy obtížně dostupné zahraniční literatury nebo testovaly různé nové metody a př́stupy. Mezi přední badatele, kteří se zabývali studiem vrcholně a pozdně středověké keramiky, můžeme zařadit také Květu Reichertovou, Miroslava Richtera a Zdeňka Smetánku, tři významné představitele, kteří působili v Archeologickém ústavu v Praze. Jejich názorový střet o možnostech datování středověké keramiky v počátcích studia výrazně ovlivnil směřování výzkumu.

Vývoj studia vrcholně a pozdně středověké keramiky v Čechách (do značné míry platí totéž i pro Moravu - srov. Doležalová 2015) je možné rozčlenit do pěti hlavních etap, pro které byly vždy určující specifické otázky, přístupy a metody. Vývoj přístupů a metod ke studiu středověké keramiky koresponduje s obecnými trendy vývoje studia středověké keramiky jak v západoevropském, tak i středoevropském měřítku. Pokud srovnáme př́stupy ke studiu středověké keramiky např́klad v publikaci Pottery in Archaeology (Orton-Tyers-Vince 1993, 4-14; Orton-Hughes 2013, 3-14) nebo v Pottery and social life in medieval England (Jervis 2014, 1-16), můžeme konstatovat, že vývoj studia vrcholně a pozdně středověké keramiky v Čechách byl velmi podobný vývoji ve Velké Británii.

Příspěvek se bude věnovat hodnocením vývoje studia užitkové (kuchyňské a stolní) vrcholně a pozdně středověké keramiky, pouze okrajově bude upozorněno na vybrané prríklady ze studií kamnářské a stavební keramiky, které lze považovat za samostatně studované badatelské okruhy charakteru oborové subdisciplíny.

\section{Nástin vývoje studia vrcholně a pozdně stř̌edověké keramiky Čechách na základě analýzy periodik}

Cílem př́íspěvku není podat vyčerpávající přehled vývoje a hodnocení bádání vrcholně a pozdně středověké keramiky s kompletní bibliografií ve smyslu bilanční studie, ale pokusit se nastínit základní vývojové etapy a tendence ve smyslu pronikání různých názorových teoretických proudů, výzkumných koncepcí a metodických otázek, a to včetně jejich kritické reflexe a charakteristiky současného výzkumu.

Z důvodu objektivizace popisu a sledování trendů ve výzkumu středověké keramiky v dlouhé časové perspektivě byla zvolena cesta spočívající na kritickém rozboru příspěvků o vrcholně a pozdně středověké keramice objevujících se ve dvou předních domácích periodikách - v časopise Archeologické rozhledy, vydávaném od roku 1949, a Archaeologia historica, sborníku a později časopisu vydávaného od roku 1976, obsahujícího příspěvky z mezinárodních konferencí středověké archeologie. Bez přímého vztahu k rozboru studií publikovaných v těchto archeologických časopisech je nutné zmínit se stručně o počátcích výzkumu středověké keramiky, kdy byla řada drobných příspěvků o středověké keramice publikována na přelomu 19. a 20. století v časopise Památky archeologické.

Počet př́íspěvků o středověké keramice publikovaných v Archeologických rozhledech, vydávaných čtyřikrát ročně, téměř dosahuje počtu př́spěvků $\mathrm{v}$ jednoročně vydávaných číslech specializovaného periodika Archaeologia historica. K hodnocení byly vybrány příspěvky z obou časopisů, v nichž je věnován vrcholně a pozdně středověké keramice dostatečný prostor (alespoň třetina vlastního textu článku se týká rozboru a hodnocení keramiky). Do analýz byly zařazeny i příspěvky o středověké keramice z Moravy a Slezska, nebot' nebyly shledány zvláštní specifika a vývojové tendence, které by se vymykaly českému vývoji. Pozornost v dalších částech textu bude ale věnována výhradně českému prostředí.

Četnost publikovaných studií v obou periodikách v rámci pětiletých cyklů ukazuje graf (obr. 1), z něhož je patrné, že vrchol bádání o keramice mladšího středověku byl v období od konce 60 . do poloviny 80 . let 20 . století. Počet je však poněkud nadhodnocen tematicky zaměřenými mezinárodními konferencemi Archaeologia historica, kde byl větší prostor věnován hmotné kultuře středověku, včetně keramiky, např́íklad v roce 1980. Po polovině 80 . let počet studií dramaticky poklesl, až v posledních letech má mírně stoupající trend, který bude vysvětlen a popsán v následujících kapitolách. 


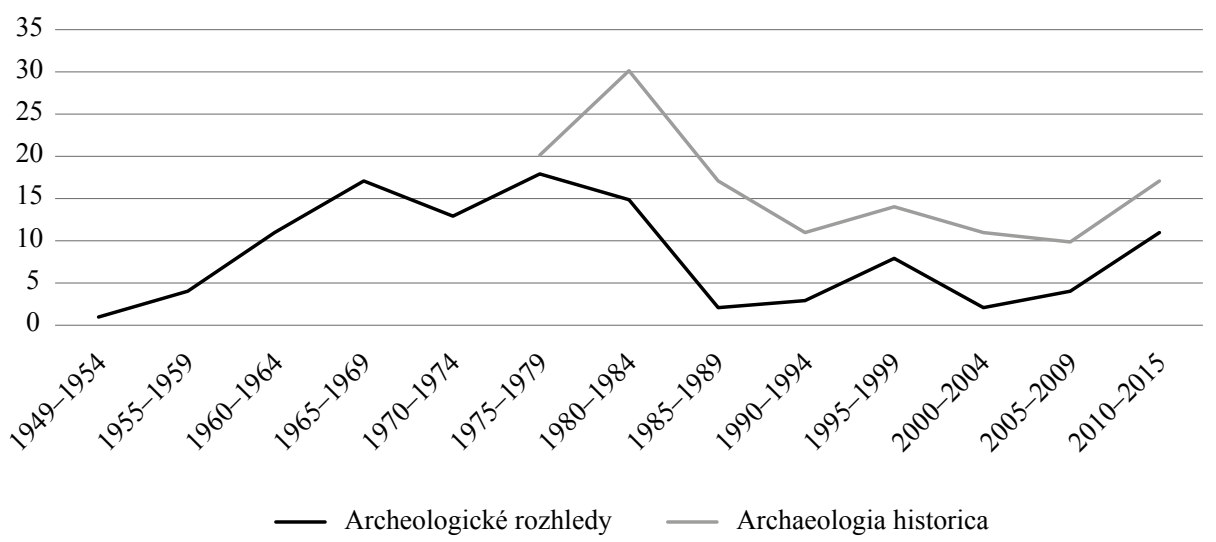

Obr. 1. Graf zobrazující četnost studií o vrcholně a pozdně středověké keramice v časopise Archeologické rozhledy a sborníku/časopisu Archaeologia historica.

Abb. 1. Diagramm mit Darstellung der Häufigkeit von Studien über hoch- und spätmittelalterliche Keramik in der Zeitschrift Archeologické rozhledy (Archäologische Rundschau) und im Sammelband/in der Zeitschrift Archaeologia historica.

Před samotným hodnocením bylo zvoleno celkem jedenáct klíčových slov a hesel, která vystihují konkrétní témata a metody, jež byly zaznamenávány u jednotlivých př́íspěvků na základě rozboru vlastního textu; u mladších čísel bylo možné využít anotací nebo souhrnů a seznamu klíčových slov. Přehled klíčových slov - témat a metod objevujících se ve studiích a jejich četnost v obou periodikách ukazuje obr. 2 . V drtivé většině se publikované články věnují základnímu hodnocení keramiky a její grafické prezentaci, nejčastěji jako komentovaný doplněk k rozboru archeologických terénních situací. Velká pozornost je v obou časopisech věnována specifickým (zvláštním) keramickým tvarům (např. pražské a kutnohorské poháry, technické misky, akvamanile, keramické plastiky, zvonky apod.). Mezi publikovanými studiemi postrádáme ty, které by se více zabývaly teoretickými a metodickými otázkami, např́íklad technologií výroby keramiky (otázky specializace a organizace), distribucí (obchod s keramikou, směnné a tržní systémy), sociálními otázkami (role keramiky ve středověké společnosti, sociální kontext, každodennost) nebo metodami deskripce keramiky, kvantifikace a statistiky. $Z$ dalších metod jen ojediněle zaznamenáváme zmínky o využití petrografie a experimentu, a to zejména až v posledních letech. Pro řadu př́spěvků je charakteristické, že málo z nich překročilo rámec jedné lokality a málokdy řeší širší otázky spojené např́ílad s regionální chronologií, distribucí keramiky apod.

Z hlediska zastoupení středověkých lokalit $\mathrm{v}$ jednotlivých př́spěvcích zcela jednoznačně dominují města, následovaná menšími opevněnými sídly a hrady, žijícími a zaniklými vesnicemi. Pouze několik málo studií se věnuje keramice z výzkumů sakrálních staveb (kostely, kláštery, kaple) a dvorců nejstarší pozemkové šlechty. Tento stav odráží i archeologické poznání těchto typů sídel. Velmi málo je také publikována keramika z výrobních areálů, včetně publikace primárních výrobních zařízení - hrnčířských pecí (obr. 3).

Na základě hodnocení periodik Archeologické rozhledy a Archeologia historica je možné definovat a popsat základní trendy vývoje studia středověké keramiky od počátků 50. let. Vývoj můžeme rozčlenit do pěti hlavních období, která jsou charakteristická svými specifickými prŕstupy ke studiu středověké keramiky, v nichž můžeme přímo nebo nepř́ímo pozorovat vlivy soudobých archeologických paradigmat a dalších názorových proudů, které vytvářeli především přední badatelé v oblasti středověké archeologie. Členění příspěvku popisujícího vývoj studia keramiky mladšího stř̌edověku následuje podobné schéma vývoje jako v publikaci Pottery in 
zhodnocení a grafická prezentace zvláštní keramické tvary kvantifikace a statistika regionální chronologie technologie výroby sociální otázky

funkce keramiky

distribuce keramiky a obchod metody a deskripce petrografie experiment

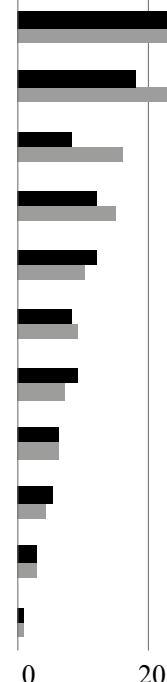

Archeologické rozhledy

Archaeologia historica

Obr. 2. Graf četnosti výskytu základních témat studia objevujících se v příspěvcích o vrcholně a pozdně stř̌edověké keramice v časopise Archeologické rozhledy a sborníku/časopisu Archaeologia historica.

Abb. 2. Diagramm zur Häufigkeit des Vorkommens von Studiengrundthemen, die in den Beiträgen über hoch- und spätmittelalterliche Keramik in der Zeitschrift Archeologické rozhledy (Archäologische Rundschau) und im Sammelband/in der Zeitschrift Archaeologia historica auftauchen.

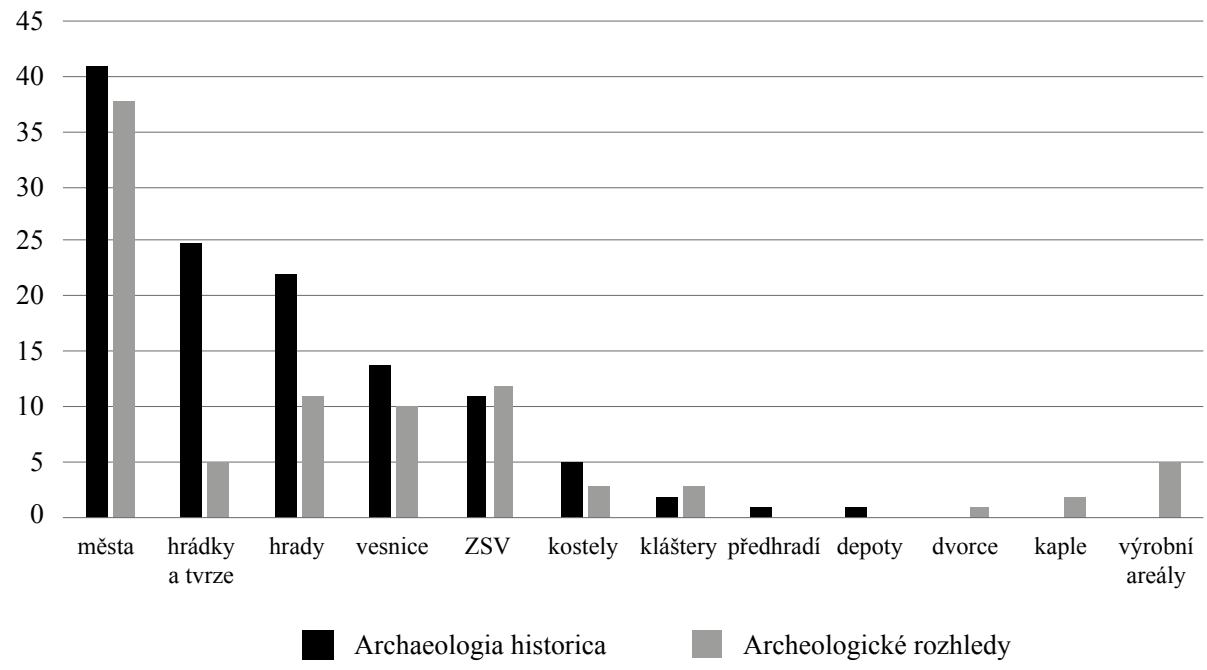

Obr. 3. Druhy archeologických lokalit s vrcholně a pozdně středověkými keramickými soubory, které byly publikovány v časopise Archeologické rozhledy a sborníku/časopise Archaeologia historica.

Abb. 3. Arten der archäologischen Fundstätten mit hoch- und spätmittelalterlichen Keramikkomplexen, die in der Zeitschrift Archeologické rozhledy (Archäologische Rundschau) und im Sammelband/in der Zeitschrift Archaeologia historica publiziert wurden. 
Archaeology (Orton-Tyers-Vince 1993, 4-14; Orton-Hughes 2013, 3-14). Pro každé období je zdůrazněn význam konkrétních badatelů s upozorněním na důležité práce - články a monografie. Pro lepší charakteristiku názorů na středověkou keramiku jsou uvedeny vybrané výstižné parafráze z citovaných prací. Dále jsou představeny metody a př́istupy používané ke studiu vrcholně a pozdně středověké keramiky, tedy základní metody práce s keramickými soubory.

\section{Konec 19. až počátek 20. století - „starožitnické“‘ období}

První období studia středověké keramiky lze charakterizovat jako „starožitnické období“, kdy na keramiku bylo nahlíženo jako na předmět s umělecko-historickou hodnotou - starožitnost. U počátků zájmu o keramiku obecně stáli umělečtí historikové a etnografové, mezi nimiž lze zmínit především J. Koulu (1855-1919), který byl mimo jiné správcem samostatného oddělení historické archeologie při Národním muzeu. Tehdejší zájem o keramiku se soustředil zejména na celé tvary vyšší umělecko-historické a estetické kvality. J. Koula v útlé knize Př́spěvky k historii hrnčiřství $v$ Čechách, která vyšla ve čtvrtém ročníku Zlaté Prahy v roce 1888 a kterou lze považovat za nejstarší publikaci ke středověké a novověké keramice v Čechách, lakonicky konstatoval: ,,...) nádobi středověké 11.-15. století stejně jako i jiné hrnčiřské výrobky té doby vykazuji po celá staletí malý pokrok jak ve tvaru, tak v řemeslném provedeni (...)“ a „(...) výzdoba středověké keramiky nenese takové známky estetické kvality jako výrobky novověké (...)“(Koula 1888, 5). To zároveň dobře ilustruje, že středověká keramika, na rozdíl od novověké, stála poněkud na okraji tehdejšího zájmu pro svoji malou řemeslnou a výtvarnou atraktivnost.

Nicméně v tomto období (na přelomu 19. a 20. století) se objevují první zmínky o archeologických nálezech středověké keramiky (zejm. v časopise Památky archeologické) - postupně byly publikovány vybrané nálezy keramiky z amatérských a poloamatérských výzkumů převážně muzejních pracovníků. Pozornost byla ve stručných príspěvcích věnována zvláštním keramickým tvarům nebo výtvarně bohaté kamnářské a stavební keramice (reliéfní kachle a dlaždice). V té době řadu článků o středověké keramice publikoval zejména K. Čermák (1852-1917), muzejník a etnograf, který prováděl výzkumy na Čáslavsku a Kutnohorsku, např́iklad výzkum v Hrádku u Čáslavi nebo čáslavských hrnčířských dílen. Shromáždil velkou kolekci středověké keramiky v čáslavské muzejní sbírce (Čermák 1896-1897; 1906; 1906a). Jeho archeologické aktivity, ale i tehdejší ojedinělé zmínky o středověké keramice, které měly charakter „hlášení“, vystihuje zejména tato pasáž z článku o čáslavském hrnčířství: „(...) při kopáni uhozeno na vrstvu nádob rozbitých i celých, jež kolem sklenuté peci rozmetány jako brak a odpadky. Nádob bylo ke stu, nejvice shledáno bezuchých hrnců na kruhu robených (...)“ (Čermák 1897, 219). V pracích K. Čermáka se poprvé objevuje základní hodnocení nalezené středověké keramiky, a také postup, který se v archeologii středověku později uplatnil - snaha navázat keramiku na historická data, např́íklad zánik hrnčířských dílen při požáru, nebo na nálezy mincí.

Další známé aktivity spojené se získáváním středověké keramiky z archeologických výzkumů jsou spojeny s učitelem a amatérským archeologem J. Švehlou (1861-1934), který prováděl řadu amatérských výzkumů v Táboře, Sezimově Ústí a na Kozím Hrádku - lokalitách spojených s husitským hnutím (Švehla 1901; 1911). Nálezům z jeho výzkumů se dostalo archeologické pozornosti až za několik desítek let.

Z dlouhého výčtu dalších „amatérských“ badatelů přelomu 19. a počátku 20. století působících lokálně $\mathrm{v}$ různých muzejních institucích a vlastivědných spolcích, kteří publikovali informace o nálezech středověké keramiky v Čechách, lze vedle J. Kouly (1908) zmínit J. Šimka (1896), F. Bareše (1901), E. Lemingera (1903), J. Löwenhöfera (1912), Č. Floriana (1914) a E. Štorcha (1927). Keramika byla v pracích nejčastěji zmíněna stručným slovním popisem a doplněna o vybrané ilustrace především celých keramických tvarů. Některé práce se věnovaly i historii hrnčířských cechů, se kterými byly některé nálezy středověké keramiky spojovány (napřs. Šimek 1896, 654-662; Bareš 1901, 21-24). O hrnčířské výrobě psali etnografové i profesionální archeologové a historikové. Např́ílad L. Niederle se zabýval problematikou hrnčířských 
kruhů (1921), Z. Winter shromáždil cenné informace o hrnčíríích zaznamenané v písemných pramenech (1906).

Pionýrské období bylo ve 40. letech ukončeno dvojicí prací, z nichž práce A. Lišky mohla již těžit ze současných výsledků umělecko-historického bádání (1943). Keramika byla historiky umění datována podle slohových analogií přebíraných z oblasti vysokého umění. Na konci 40 . let publikovala první práci začínající badatelka K. Reichertová, která byla výraznou osobností výzkumu vrcholně a pozdně středověké keramiky v následujícím období. V práci publikované ve Zprávách památkové péče podala stručný nástin vývoje středověké keramiky z archeologického hlediska (na základě hodnocení nálezů keramiky z českých hradů a z muzejních sbírek) a vyzdvihla význam keramiky jako datovacího prostředku pro středověkou architekturu (Reichertová 1948).

Výzkum středověké keramiky a obecně i středověké archeologie byl ve 30 . a 40. letech teprve $\mathrm{v}$ počátcích. To se týká i stavu zpracování nálezových souborů středověké keramiky postupně získávaných z archeologických výzkumů. I. Borkovský v článku o arabském poháru z výzkumu studny na Pražském hradě, odkud tento pohár pocházel, lakonicky konstatoval: ,„(..) je tu mnoho rozbitých nádob, z nichž přes 100 ks bylo rekonstruováno, (...) jsou tu různé tvary, druhy a velikosti nádob různého technického provedeni a určení. Keramika, bude-li jednou zveřejněna, ukáže nám bohatost tvarů a nádob, použivaných v královské kuchyni 13.-14. století (...)“(Borkovský 1946, 193).

\section{Padesátá až šedesátá léta, počátky systematického studia - typologická fáze}

Počátky skutečného odborného badatelského zájmu o středověkou keramiku lze spatřovat až v poválečném období a v 50. letech, kdy se ze slovanské archeologie vyděluje archeologie mladšího středověku zabývající se rámcově obdobím 12./13. až 15./16. století. Časové ukotvení a témata studia historické (středověké) archeologie vymezil v Časopise Národního muzea v článku O úkolech historické archeologie V. Denkstein (1906-1993), přičemž vyzdvihl význam památek hmotné kultury včetně středověké keramiky (1953). Jeho článek vycházel z již postupně rostoucího zájmu o historické a umělecké památky včetně památek archeologických (např. již Drobná 1951).

Jako mladé odvětví byla archeologie mladšího středověku postupně institucionálně ukotvována a vymezována vůči ostatním disciplínám (historie, etnografie, dějiny umění) a zároveň byla hledána základní témata studia, mezi nimiž v první řadě stál zájem o hmotné památky středověku (podrobně např. Klápště 2016, 3-13; Smetánka 1987, 279-293; 2014). Tehdejší bádání bylo silně ovlivněno marxistickou historiografií a historickým materialismem - na archeologické památky hmotné kultury bylo nahlíženo jako na prostředky k řešení výrobních vztahů a třídní diferenciace společnosti (k marxismu v české archeologii např. Neustupný 2017; ve vztahu ke keramice již Štěpánek 1971, 122).

Z hlediska studia středověké keramiky lze za iniciační považovat článek J. Böhma (1901-1962) K otázce vzniku feudalismu v českých zemích publikovaný v roce 1951 v etnografickém časopise Český lid, který poprvé otevřel širší diskusi o středověké keramice (Böhm 1951). J. Böhm se věnoval období raně středověkému (8.-9. století) a vyzdvihoval význam keramiky jako předmětu k řešení výrobních vztahů ve společnosti. Konstatoval zároveň vyšší technologickou vyspělost a specializaci mladší stř̌edověké keramiky na rozdíl od „slovanské keramiky“. Počátky specializace hrnčířské výroby (řemeslné malovýroby) spatřoval v první polovině 9 . století, kdy došlo k rozšíření rychle rotujícího kruhu. Narůstající specializaci ve výrobě považoval za zárodek feudálních vztahů a třídní diferenciace společnosti. Na zmíněný článek reagoval v témže časopise K. Černohorský (1896-1982), moravský muzejník a etnograf, který poprvé detailněji popsal technologii výroby středověké keramiky na hrnčiřských kruzích (nálepovou techniku) a zpochybnil např́ílad J. Böhmem a dalšími badateli proklamovanou existenci rychle rotujícího kruhu před 13. stoletím. Upozornil také na problematiku hrnčířských značek (Černohorský 1952; 1953). 
K. Černohorský vycházel především z polské a ruské etnografické literatury (Hołubowicz 1950; Rybakov 1948).

Výzkum mladší středověké keramiky, na rozdíl od keramiky raně středověké, byl v 50 . letech stále v počátcích, jak konstatovala v článku v Českém lidu v roce 1953 historička umění Z. Drobná (1907-1988). Bádání o středověké keramice si kladlo především jednoduché empirické otázky, bez hlubšího teoretického pozadí. Kličcovou otázkou bylo především datování a poznání vývoje jednotlivých keramických tvarů a hledání kvalitativních rozdílů mezi vrcholně a raně středověkou (slovanskou) keramikou: ,(...) tuto souvislost je třeba sledovat po stránce tvarové, technologické a výzdobní a vyvodit z jejich proměn poučení pro vývoj výrobnich, hospodárských a společenských vztahů (...)“1 (Drobná 1953, 77).

Z. Drobná poprvé definovala základní témata studia, mezi něž zařadila v poněkud nelogickém pořadí studium značek na dně nádob, sestavení vývojových typologických řad, ceny výrobků a jejich „výtvarné krásy“ (Drobná 1953, 77-78). Kritizovala také dosavadní umělecko-historické prrístupy, které si především všímaly výtvarně hodnotnějších a luxusnějších výrobků. Upozornila na zajímavé kolekce keramiky z fondů regionálních muzeí, zejména těch, které pocházely z výzkumů lokalit spojených s husitským obdobím (Tábor, Kozí hrádek, Sezimovo Ústí). Zmiňované lokality nebyly vybrány zřejmě nijak náhodně, nebot' zapadaly do konceptu výzkumu husitských památek, podporovaného tehdejší marxistickou ideologií (k tomu např. Klápště 2016, 12). Není pochyb o tom, proč se pozornost badatelského zájmu o pozdně středověkou keramiku soustředila na „husitské“ období, ale objektivní příčinou bylo i to, že tehdy nebyly dostupné soubory středověké keramiky, ty byly průběžně získávány až systematickými a záchrannými archeologickými výzkumy středověkých lokalit v 50. a 60 . letech.

V poválečném období byly zahájeny velké systematické výzkumy hradských center raného středověku, při nichž byla nacházena (zejména u center $\mathrm{s}$ kontinuálním sídelním vývojem) keramika vrcholně a pozdně středověká. Vyzdvihnout lze zejména výzkumy I. Borkovského (1897-1976), archeologa neodmyslitelně spojeného s výzkumem Pražského hradu, jenž zároveň patří k prvním badatelům, kteří rozdělovali keramické nálezy podle stratifikace terénu. Jde například o výzkumy kostela Panny Marie, Černé a Bílé věže, románského opevnění Pražského hradu nebo Anežského kláštera (Borkovský 1953; 1959; 1962). Získávaná keramika byla východiskem pro datování stavebních fází a pro podporu interpretace nálezových situací.

Teprve v 50. letech byly zahájeny výzkumy lokalit mladšího stř̌edověku, mezi něž patří výzkum tvrzí Martinice u Votic (Reichertová 1952), Zrůbek a Zvírotice, latránu v Příběnicích (Hejna 1954), románské baziliky v Teplicích (Hejna 1956). Pro datování keramiky 13. století byl důležitý systematický výzkum zaniklého městečka Sekanky - Hradišt'ka u Davle (Kaván 1956; Richter 1957; 1963) a pro keramiku 14. a 15. století pozdější výzkum zaniklého předměstí Sezimova Ústí (Richter-Hrdlička 1964; Smetánka-Richter-Špaček 1964; Hrdlička-RichterSmetánka 1966). Nelze opomenout ani výzkumy vesnických sídlišt' v Krašovicích, Červené nad Vltavou (Hejna 1960; 1962; 1964) nebo zaniklých středověkých vsí na katastru Štíhlic a Bylan (Smetánka 1959; 1962).

První badatelkou, která se systematicky věnovala keramice vrcholného a pozdního středověku, byla již zmíněná K. Reichertová (1921-2004), její výzkum se datuje od konce 40. let (Reichertová 1948). K. Reichertová se poprvé zabývala metodickými otázkami studia, především ve smyslu hledání kvalitních datovacích opor - zmínit lze např́íklad její krátkou studii v Archeologických rozhledech z roku 1957. Upozorňovala především na získávání dobře datovatelných nálezů keramiky, které by byly oporou pro postihnutí tvarového a typologického vývoje střredověké

1 Podobné souvislosti byly řešeny i mezi keramikou pozdně středověkou a tzv. keramikou lidovou, kdy byly hledány kvalitativní rozdíly a časové vymezení. Na novověké lidové keramice byly kromě národního a etnického akcentu spatřovány vlivy raného kapitalismu, který ovlivnil výtvarnou stránku výrobků, na rozdíl od keramiky lidové, jež byla usměrňována jak samotnými tvůrci, tak spotřebiteli v rámci výrobních vztahů. Středověká keramika nebyla zařazena do oblasti lidové kultury, nebot' sloužila oběma třídám bez rozdílu (viz Scheufler 1963). Až úsměvně dnes působí pasáž marxismem ovlivněného textu V. Scheuflera, připodobňující stř̌edověkou realitu k, ,(...) socialistickému státu, který má ovšem před kapitalistickým výhodu, že má možnost zasahovat v masovém měrítku do výtvarné a funkčni stránky výrobků a tím usměrňovat vkus spotřebitele (...)“ (Scheufler 1963, 38). 
keramiky. Za klíčové „datovací opory“ považovala zejména mincovní depoty v keramických nádobách a soubory $\mathrm{z}$ lokalit $\mathrm{s}$ krátkodobou etapou existence - zejména hradů, u nichž je známo datum založení nebo zániku, popř́ípadě obojí (Reichertová 1956). V roce 1962 obhájila kandidátskou disertační práci Úvod do studia středověké keramiky a v roce 1965 publikovala práci, která vyšla v řadě Archeologické studijní materiály III, Středověká keramika ze Sezimova Ústí, Tábora a Kozího Hrádku - Přispěvek ku chronologii a tvarosloví středověké keramiky, v níž zpracovala starší nálezy keramiky ze středověkých lokalit spojených s husitským obdobím, na které již dřive upozornila Z. Drobná (1953).

Jednalo se o první ucelenou archeologickou práci, která shrnovala stav tehdejšího poznání středověké keramiky, včetně historického úvodu, přehledu literatury a výzkumů. Z hlediska technologie výroby vrcholně středověké keramiky na hrnčiřských kruzích se ztotožnila s názory K. Černohorského. Zároveň se v této práci objevuje podrobnější nástin klasifikace a terminologie středověké keramiky - popis tvarů nádob, profilace okrajů a výzdoby. Snahou práce bylo přinést i určitou standardizaci popisu středověké keramiky. První pokus o nástin standardizace metod popisu a dokumentace keramiky učinil již dříve archeolog-numismatik P. Radoměrský v Muzejní a vlastivědné práci v roce 1964 .

Studium keramiky výrazně ovlivňovaly osobnosti nově se rozvíjející historické archeologie, které často měly umělecko-historické vzdělání (Z. Drobná, K. Reichertová), což se projevuje v užším spektru otázek nepřímo spojených s problematikou dějin umění. Při rozboru vrcholně a pozdně středověké keramiky bylo zpočátku pouze málo využito zkušeností, které nashromáždila pravěká a slovanská archeologie (srov. Štěpánek 1971, 122).

Mladá archeologie středověku po metodické stránce doháněla archeologii pravěkou, ve které byly již dlouho etablovány typologické metody třídění artefaktů. Období 50. až 60 . let můžeme z hlediska výzkumu středověké keramiky označit jako typologickou fázi, nebot' byly položeny základy vývoje keramických typů a funkčních tvarů středověkých nádob, včetně systematiky jejich hodnocení. S rozvojem typologických metod se postupně ukázalo, že vývoj keramiky byl daleko složitější, než jak jej nabídla schémata vypracovaná na základě zjednodušených umělecko-historických kritérií (Štěpánek 1971, 123), a neodpovídal skutečnosti.

Pozornost tehdejšího bádání se $\mathrm{v}$ počátcích typologického studia soustředila na možnosti využití datovacích opor pro absolutní chronologii, na jejichž základě bylo možné vypracovat podrobnější typologii stř̌edověké keramiky. Většina dosavadních shromážděných nálezů keramiky pocházela bud' ze starších výzkumů bez stratigrafických souvislostí, nebo z nesystematicky vytvořených kolekcí středověké keramiky v muzejních sbírkách. V počátcích studia byla proto velká pozornost soustředěna na hodnocení hromadných mincovních depotů v keramických nádobách, které byly považovány ,za nejdůležitějši pramen pro absolutni chronologii“. V té době byla publikována řada soupisových prací mincovních depotů, z nichž nejstarší byla již klasická práce R. Turka věnovaná nálezům denárových ražeb mincí (1948; 1948a). Později přibyly další práce K. Reichertové, M. Richtera a P. Radoměrského, kteří heuristicky shromáždili nálezy mladších domácích ražeb (brakteátů, českých grošů), včetně ražeb zahraničních mincí (Reichertová 1959; Richter 1959; Radoměrský 1963). Vrcholem badatelského zájmu o depoty nádob s mincemi pak bylo stěžejní dílo P. Radoměrského a M. Richtera - Korpus české keramiky datované mincemi, které bylo publikováno s jistým zpožděním až v roce 1974 a zahrnovalo celkem 195 lokalit s nálezy mincí v keramických nádobách $\mathrm{z}$ období od 11. do 16. století, přičemž došlo i k revizi a doplnění starších soupisových prací. Kromě publikovaného katalogu bylo na základě dochovaných nádob provedeno i celkové zhodnocení tvarového vývoje keramiky v jednotlivých obdobích (Radoměrský-Richter 1974).

Postupně bádání o středověké keramice spělo k názoru, že dochází k rozporu v rozdílném stáŕí nádoby a mince, tzn. že mezi dobou zakopání depotu, zjištěnou analýzou skladby mincovního fondu, a intervalem výroby a užívání nádoby a mince existuje určitý časový rozdíl. Upozorněno bylo na chybné přejímání nálezů nádob s mincemi jako pouhých „,analogii'“, které může vést k závažným omylům (např. Smetánka 1977, 245). Problémem nálezů keramických nádob 
s depoty mincí bylo i to, že nebylo možné na keramických nádobách sledovat nástupy a doznívání určitých jevů (typ, varianta okraje, výzdoby, technologické detaily apod.). Navíc srovnávacích nálezů depotů mincí v keramických nádobách nebylo tolik, aby bylo možné na jejich základě komplexně postihnout vývoj keramiky v určitých regionech (obr. 4).

Proto byly hledány i jiné cesty vedoucí k tvorbě relativní chronologie bez možnosti externího datování, které byly poprvé diskutovány v článku Z. Smetánky a M. Richtera vzešlého $\mathrm{z}$ konference v Liblicích - Př́spěvek $k$ metodice studia středověké keramiky v Čechách (1958), ve zkrácené verzi pak publikovaného v Archeologických rozhledech (1959). Z. Smetánka a M. Richter upozornili na hodnotu nálezových situací s keramikou, které bylo možné vztáhnout k historickým datům, např́klad požárové vrstvy, je-li známé datum požáru, nebo na keramiku z hradů, tvrzí či dalších objektů krátkodoběji osídlených, kde bylo možné získat alespoň jedno z mezních absolutních dat (založení nebo zánik), nebo dokonce obě, z historických pramenů. ${ }^{2}$

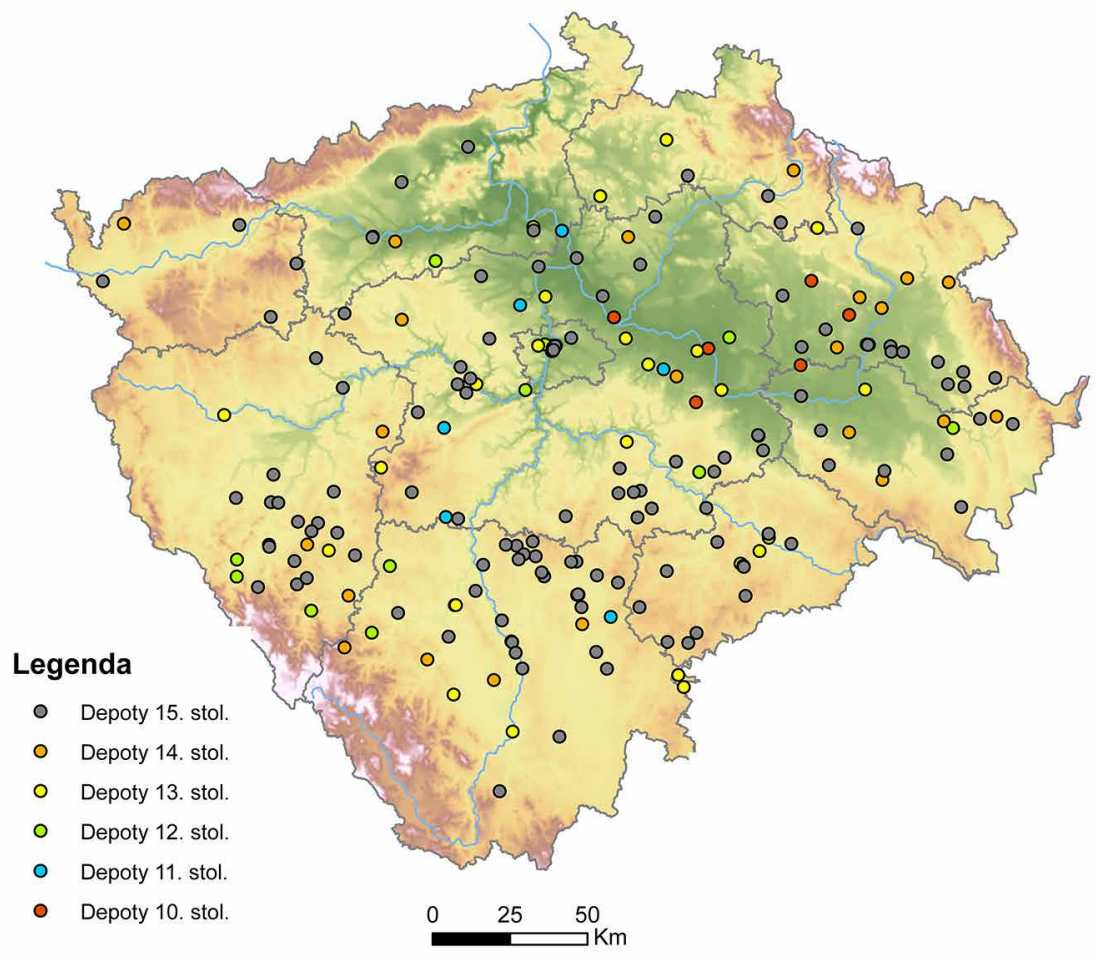

Obr. 4. Zastoupení depotů mincí v keramických nádobách v rámci Čech ukazuje tato mapa, která jednoznačně dokládá, že těžiště nálezů mincovních depotů v keramických nádobách leží ve 13. a 15. století. Mapa je doplněna o další nové nálezy depotů mincí v keramických nádobách publikované v posledních letech. Vytvořil L. Čapek.

Abb. 4. Diese Karte zeigt auf, wie Hortmünzen in Keramikgefäßen im Rahmen von Böhmen vertreten sind und belegt eindeutig, dass der Schwerpunkt an Funden von Münzdepots in Keramikgefäßen im 13. und 15. Jahrhundert liegt. Die Karte wurde um weitere neue Hortmünzfunde in Keramikgefäßen ergänzt, die in den letzten Jahren publiziert wurden. Zusammengestellt von L. Čapek.

2 Př́ikladem může být např́iklad Nový hrad u Kunratic, u kterého je známé jeho datum založení Václavem IV. roku 1411 a jeho dobytí pražany v roce 1421 , nebo manský dům na Křivoklátě, který byl postaven okolo roku 1400 a zanikl požárem 18. března 1422! 
U lokalit s delší dobou užívání bylo nutné pracovat tzv. eliminačni metodou spočívající v hledání keramických znaků mezi časově blízkými soubory keramiky intervalově datovanými bud' ante quem nebo post quem založením nebo zánikem lokality. Tzn. hledání takových znaků na vývojově starších lokalitách, které chybí v porovnání s lokalitami mladšími. Ukázalo se však, že lokalit se známými daty není v Čechách mnoho (obr. 5). Eliminační metoda se uplatnila při sestavování regionálních keramických sekvencí, zejména pak v 70. letech, kdy již díky archeologickým výzkumům přibylo větší množství srovnávacích souborů. Autoři také diskutovali možnosti typologické metody při studiu keramiky, přičemž konstatovali, že je velmi závislá na kvalitě nálezových celků, a vyzdvihli úlohu vertikální a horizontální stratigrafie - tedy postup, který byl již běžně uživán v prehistorické archeologii.

Jako problematické se ukázalo datování keramiky podle slohových analogií přebíraných z „oblasti vysokého umění, spočívající na evolucionistickém předpokladu, že se středověká keramika vyvíjela v souladu s vývojem středověké architektury a umění. Způsob datování propagovaný $\mathrm{v}$ počátcích studia $\mathrm{K}$. Reichertovou - „(...) protože se jedná o formu středověkou, lze předem metodicky předpokládat, že zákonitost jejího vývoje bude totožná se zákonitostí ostatní středověké formy, např. jako v architektuře (...)“(1955, 163; nebo již dříve 1948, 90) - se ukázal jako velmi problematický, nebot' nebylo možné dospět k vzájemné synchronizaci uplatňování slohových zákonitostí na keramice a v architektuře, umění nebo ikonografii (srov. Smetánka-Richter 1958, 140-143; Richter-Smetánka 1959, 87). Přesto se ještě v 60. letech o tomto způsobu datování středověké keramiky v literatuře uvažovalo (např. Hejna 1967).

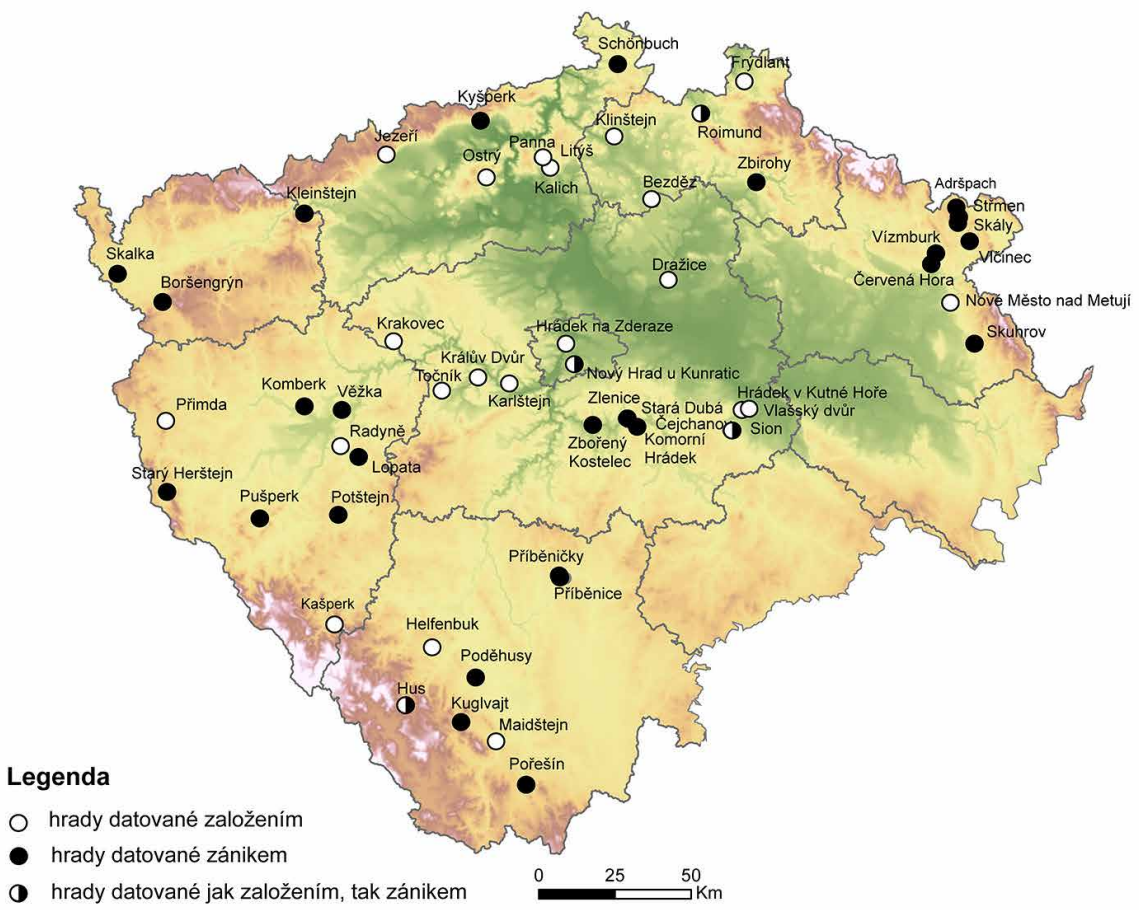

Obr. 5. Hradní lokality v Čechách, u nichž známe datum založení, zániku nebo obojí. Vytvořil L. Čapek.

Abb. 5. Burgfundstätten in Böhmen, bei denen uns Gründung, Untergang oder beides bekannt ist. Zusammengestellt von L. Čapek. 
V 60. letech byly publikovány soubory středověké keramiky pocházející z řady záchranných a předstihových archeologických výzkumů. V roce 1966 byla publikována práce A. Hejny (1920-1986) Středověká vesnická keramika v Čechách, která se opírala o hodnocení souborů keramiky získaných archeologickými výzkumy vesnických sídlišt', zejména v Krašovicích a Červené nad Vltavou (Hejna 1966). V práci byly mimo jiné řešeny otázky hospodářské a společenské, např. specializace a organizace hrnčířské výroby, ovšem již ve své době se značnou tendenčností a schematičností, projevující se napríílad v opakování významu keramiky jako prostředku k poznání vývoje výrobních sil. Upozorněno bylo na regionální odlišnosti ve vývoji keramiky v Čechách, kde byly hledány souvislosti s již tehdy anachronickým „kmenovým rozdělením země “ (!). Cílem práce A. Hejny bylo zabývat se na základě rozboru keramiky odlišnostmi ve vývoji hradištní a mladší (vrcholně) středověké keramiky na přelomu 12. a 13. století, přičemž v rozpadu původně jednotného charakteru starší hradištní keramiky vycházející ze slovanského základu bylo spatřováno především pronikání vnějších vlivů: „(...) proti situaci hrnčírské výroby $v$ době hradištni musime počitat ve středověké keramické produkci s častějším, silnějším a zároveň složitějším pronikáním a prolináním vlivů jednotlivých dílen a jejich okruhů z téhož i z cizího etnického prostředí, dosud však musime počitat i s přetrváváním domácí výroby, zvláště na vesnicích (...)“(Hejna 1966, 316). Práce měla především sledovat změny na pozdně hradištní keramice v klíčovém období 12. a 13. století. Již na tehdejší dobu bylo vyhodnocení keramiky nedostatečné a málo průkazné a vycházelo především z empirického pozorování, což bylo předmětem kritické recenze Z. Smetánky (1969, 399-402), který představil důkladnější analýzu pozdně hradištní keramiky v roce 1973.

V 50. a 60. letech se vedle poznání vývoje keramických typů pozornost badatelského zájmu soustředila na technologicky zajímavé skupiny středověké keramiky. Jednalo se především o červeně malovanou keramiku, u níž byl diskutován její původ a bylo upozorněno na centra výroby v severních Čechách (Reichertová 1955; Richter-Smetánka 1958). Další sledovanou otázkou byly počátky nejstarší polévané (glazované) keramiky v Čechách (Richter 1961), při jejímž zkoumání byly poprvé využity spektrální analýzy glazur (Richter 1961, 575; Smetánka-Topolová 1967).

Bádání o středověké keramice chyběly výzkumy primárních výrobních zařízení - hrnčířských dílen a pecí. Dosavadní starší výzkumy výrobních zařízení se týkaly novověkého hrnčírství, nebo nebyly při starších výzkumech podrobněji dokumentovány (např. Hořovice - Reichertová 1962). Teprve až ve druhé polovině 60 . let byly publikovány první výsledky výzkumu hrnčířských pecí z 13. století - Kostelec nad Orlicí a 15. století - Bakov nad Jizerou (Richter 1967; Hrdlička 1967). Současně probíhal výzkum hrnčiřsských dílen v Sezimově Ústí, který byl bohužel publikován až se značným časovým odstupem.

$\mathrm{V}$ publikacích o středověké keramice $\mathrm{z}$ archeologických výzkumů můžeme postupně zaznamenat snahy o přehlednou prezentaci typologických znaků, zejména okrajů a výzdoby rozdělených podle jednotlivých skupin a typů (Smetánka 1959; 1962; Nechvátal 1965). Větší pozornost byla také věnována výběru dokumentované keramiky, přičemž cílem bylo představit vůdčí keramické typy.

Na počátku výzkumu nebylo obvyklé pracovat s kvantifikací keramických prvků. Jeden z prvních badatelů, který se zabýval četností sledovaných tvarů, typů okrajů a výzdoby, byl Z. Smetánka při rozboru středověké keramiky z Černokostelecka (1959, 688-690). Diskutovány byly poprvé možnosti popisné statistiky, která „(...) umožní exaktnější a celistvějšsi popis materiálu a kontrolu průkaznosti kvantitativních rozdilů, z nichž vyvozujeme závěry (...)“(RichterSmetánka 1959, 92).

Kvantifikace znaků vyplynula především z množství získávaných keramických nálezů při systematických, předstihových a záchranných archeologických výzkumech středověkých lokalit, jejichž empirické zpracování naráželo na metodické obtíže. V této souvislosti lze citovat výstižný úryvek z článku B. Nechvátala o výzkumu tvrze v Ervěnicích na Chomutovsku: „Značné množství nálezů keramiky, s kterou se setkáváme na všech středověkých lokalitách, v nichž osídlení trvalo delši dobu, vyžaduje i hledáni nových metod jejího zpracování. Dosavadní, prevéazzě 
empirické metody, nedovolují tento rozsáhlý materiál vyhovujicim způsobem zvládnout zpracovat a postihnout důležité kvantitativní a kvalitativní znaky" (Nechvátal 1965, 837).

Klíčovým oborovým milníkem byla výstava Středověká keramika v Československu, která se konala v Národním muzeu v Praze v květnu 1962 až červnu 1963. Libreto a scénář výstavy vypracoval kolektiv pracovníků historicko-archeologického oddělení Národního muzea pod vedením Z. Drobné (Drobná red. 1963). Na scénáři k výstavě se podíleli za Čechy také A. Hejna a P. Radoměrský. Prezentovaná středověká keramika byla zapůjčena $z$ velkého počtu institucí - celkem z 31 muzeí z Čech, 18 z Moravy a 16 ze Slovenska! Většinou se však jednalo o starší sbírkové kolekce keramiky s menším zastoupením keramiky z archeologických výzkumů středověkých lokalit. Výstava podávala $v$ několika prezentačních rovinách pohled do výroby, funkce, tvarové a výzdobné bohatosti středověké keramiky od 11. do počátku 16. století. Katalog k výstavě vyšel v české, německé, ruské, francouzské a anglické jazykové verzi.

Vrcholem typologického období se stala syntéza ke středověké keramice od K. Reichertové a V. Nekudy Středověká keramika v Čechách a na Moravě publikovaná v roce 1968. Českou část vypracovala právě K. Reichertová. V této práci byly shrnuty dosavadní výsledky tehdejšího bádání, včetně historického úvodu, $\mathrm{v}$ němž byly shromážděny informace o středověkých hrnčírích v písemných pramenech, které již dříve sestavil Z. Winter (1906). Kapitola věnovaná hospodářskému a sociálnímu postavení hrnčířů se nevymanila jisté tendenčnosti týkající se specializace a organizace hrnčířské výroby, která př́iliš nereflektovala současný historický diskurz (viz Štěpánek 1971, 124). V knize je podrobně popsána metodika klasifikace středověké keramiky, která je založena na popisu tvaru nádoby (tvarosloví, tektoniky), dále popisu profilace okraje a výzdoby. Důraz byl kladen především na uměleckou stránku hodnocené užitkové a kamnářské keramiky a snahu hledat mezi keramikou vzájemné analogie a zasadit je do společenského dobového kontextu. Upozaděno bylo studium technologických znaků, které přejalo dosavadní názory na techniky tváření keramiky formulované již dříve K. Černohorským (1952) či polským badatelem W. Hołubowiczem (1950). Sledovány byly dvě základní techniky formování nádob (obtáčení a vytáčení), doložitelné pouze na dnech nebo vnitřních stěnách nádob. Výsledky jedné z prvních petrografických analýz nebyly využity a zcela opomenuty zůstaly metody kvantifikace keramiky umožňující srovnávání kvantitativního zastoupení prvků na keramice mezi jednotlivými středověkými soubory. Málo pozornosti bylo věnováno vypracování relativní chronologie, větší důraz byl přikládán pramenům absolutním (písemné prameny, depoty mincí v keramických nádobách). Bezproblémový nezůstal ani katalog nálezů vycházející z nekritického hodnocení souborů keramiky ze středověkých lokalit, mezi nimiž dominantní místo zaujaly soubory keramiky z hradů a neuspořádané komplexy keramiky ze sbírek městských muzeí pocházejících ze starších výzkumů. ${ }^{3}$ Opomenuty byly vybrané nálezy keramiky nově získané archeologickými výzkumy v 50. a 60 . letech. Důraz byl kladen především na celé keramické tvary a v omezené míře na zlomkovou keramiku. Přestože je kniha zatížena řadou problémů, včetně metodických, na které upozornili v možná až př́liš kritické recenzi M. Richter a Z. Smetánka (1970), jež vyvolala místy až emocionální reakci obou autorů obhajujících své metodické postupy (Nekuda 1970, 123-124; Reichertová 1971, 118-122), stále představuje základní syntézu ke středověké keramice. Bohužel je z ní dodnes excerpována řada již překonaných názorů a omylů, týkajících se např́iklad technologie výroby keramiky. Touto knihou, která koncepčně spadá do kulturně-historického studia středověké keramiky, také završila K. Reichertová publikační aktivitu, jejímž předmětem byla mladší stř̌edověká keramika. Od té doby publikovala pouze několik výběrových článků o středověké keramice (např. z Anežského kláštera). Důvodem bylo i to, že výzkum středověké keramiky se začal rozvíjet jiným směrem, jak naznačovala zmiňovaná recenze Z. Smetánky a M. Richtera. ${ }^{4}$

\footnotetext{
3 K. Reichertová uvádí, že celkem bylo lístkově a inventarizačně zpracováno a klasifikováno zhruba osm a půl tisíce keramických nálezů v Čechách, pro moravskou oblast jich bylo zkatalogizováno čtyřicet tisíc! Pracovalo se pouze se soubory, k nimž byly dostupné záznamy v nálezových zprávách, muzejních katalozích nebo v literatuře (Reichertová 1971, 120).

4 Autoři mimo jiné vytýkali nereprezentativnost výběru hodnocené keramiky a nedostatek analytických metod (absence využití př́rodovědných a statistických analýz), které zároveň označovaly nástup nového procesuálního paradigmatu v archeologii.
} 
Vedle užitkové keramiky lze v tomto období zmínit průkopnické práce Z. Smetánky týkající se poznání technologie výroby, typologie a morfologie středověkých kachlů. Téma středověkých kachlů bylo ostatně předmětem jeho kandidátské práce obhájené již v roce 1960. Publikačně byly ale výsledky zhodnoceny až koncem 60 . let a dodnes patř́ mezi stěžejní práce o středověkých kachlích a kamnářské výrobě v Čechách (Smetánka 1968; 1969a).

České bádání je nutné sledovat v širším středoevropském kontextu, nebot' i tam docházelo k výrazným posunům ve výzkumu středověké keramiky. Vliv na formování výzkumu u nás měly publikace německých archeologů, např́iklad práce W. Janssena (Janssen 1966) a U. Lobbedeye (Lobbedey 1968), které byly hojně citovány i v domácí literatuře. Zřetelné inspirace, zejména v otázkách týkajících se technologie výroby, pocházely ze studia prací polského archeologa J. Kruppého o vrcholně středověké keramice z Varšavy - Starého Města (Kruppé 1961; 1968).

\section{Sedmdesátá a osmdesátá léta, vlivy procesuální archeologie - formalizace postupů, tvorba regionálních sekvencí}

V 70. letech je možné v pracích o středověké keramice spatřovat ohlas nastupujícího nového (procesuálního) paradigmatu. Koncem 60. let byla publikována vlivná práce Analytical Archaeology předního procesualisty D. Clarka (1968), jejíž text nepochybně ovlivnil řadu archeologů i u nás, včetně badatelů v oblasti středověké archeologie.

Ve studiích o keramice můžeme spatřovat vlivy procesuálního paradigmatu především v nových analyticko-syntetických metodách práce s keramickými soubory a ve snaze o exaktnější vědecké pojetí studia s důrazem na získávané vlastnosti keramických dat (Smetánka 1970). Větší důraz byl kladen na reprezentativní výběr hodnocených souborů keramiky (tzv. reprezentativnost vzorku), které si vyžádalo zpracování fragmentárního keramického materiálu, a byly propracovány metody deskripce. Kromě celých tvarů a jejich morfometrie byla pozornost věnována detailní deskripci morfologických prvků, které začaly být rozčleňovány na jednotlivé typy, podtypy, varianty a subvarianty a označovány numerickými kódy (podle způsobu známého z oblasti numerické taxonomie). Více byly sledovány také metrické vlastnosti keramiky, např́klad průměry a výšky okrajů (zejména vzhůru vytaženého okraje a okrajů typu okruží, u nichž se předpokládala jistá chronologická závislost). Procesuální archeologie obohatila výzkum keramiky o nové metody v oblasti kvantifikace a statistického testování. Poprvé byla také využita již delší dobu známá metoda seriace, pro uspořádání vývoje keramických sekvencí.

Na počátku 70. let vyšla důležitá práce I. Pavlů o pražské keramice 12. a 13. století (1971), která byla pozitivně hodnocena, nebot' se jednalo o jednu z prvních prací, jež se zabývaly kritikou pramene a výpovědními možnostmi keramických souborů (srov. Smetánka 1974, 480-481). Důraz byl také kladen na kvantifikaci znaků a chronologickou a statistickou reprezentativnost vzorku. Pro tvorbu relativní chronologie pražské keramické sekvence byla použita jednoduchá metoda seriace (Pavlů-Pavlů 1971). Práci I. Pavlů lze také charakterizovat jako jednu z prvních prací o středověké keramice, kde můžeme pozorovat patrný vliv nastupující procesuální archeologie.

Práce se stř̌edověkými keramickými soubory narážely na metodické obtíže, které vyplývaly ze zpracovávání fragmentárního materiálu, nebot’ nebylo možné získat spolehlivé údaje o skutečném počtu tvarů nádob, a proto získané nebo vypočítané údaje musely vycházet $\mathrm{z}$ určitého odhadu a pravděpodobnosti. Zdeněk Smetánka využil např́íklad čtyři kategorie spolehlivosti pro stanovení zastoupení keramických tvarů, které byly statisticky testovány pomocí metody inverzní $\sin \varphi$ transformace $(1973,472)$.

Středověká keramika začala být také od 70. let studována $\mathrm{v}$ širším geografickém a prostorovém kontextu. Zásady eliminační metody a pravidla tvorby relativní chronologie, formulované Z. Smetánkou a M. Richterem, se uplatnily zejména u vytvárení regionálních keramických sekvencí. Detailně byl zkoumán vývoj keramiky v některých regionech, napr. na Černokostelecku (Klápště 1978, 448-459) nebo ve východní části středních Čech (Durdík 1980). 
Z regionálního hlediska byla nejlépe rozpracována chronologie středověké keramiky severočeského Polabí, především zásluhou průkopnické studie M. Zápotockého (1978). Ten využil postupy, které byly blízké zahraničním procesualisticky zaměřeným pracím o keramice využívajícím numerickou deskripci. V první fázi metoda spočívala ve výběru statisticky reprezentativních keramických souborů ze studovaných objektů (tzv. entit) z regionu na základě četnosti sledovaných znaků (těžiště tvořily především soubory ze severočeských hradů, v menší míře z měst). Dále byly definovány na základě deskripce hlavní studované znaky na keramice (tvar nádoby, okraje, příčný profil ucha, tvar a úprava dna, ornamentace), pro něž bylo vytvořeno jednotné alfanumerické kódování. Poté byly sestaveny matice, v nichž byly seřazeny podtypy okrajů a výzdoby podle metody Stehliho těžiště a pomocí jejich seriace byly hledány korelace mezi objekty (entitami). Výsledek v podobě seriačních diagramů umožnil vytvoření statisticky podložené relativní posloupnosti znaků, jež byly interpretovány v chronologickém smyslu a rozděleny do jednotlivých horizontů na základě validace se stratigrafickými údaji nebo v komparaci se soubory z lokalit se známými historickými daty či z depotů mincí v keramických nádobách.

Ojedinělá studie M. Zápotockého, který se středověké archeologii věnoval pouze okrajově, se nesetkala $\mathrm{s}$ téměř žádným pozitivním ohlasem (autorovi článku se nepodařilo dohledat žádnou recenzi). Jedním z kritických aspektů dopadu práce bylo podcenění interpretační stránky a nedostatečná kritika výpovědní hodnoty získaných souborů keramiky, na nichž byla postavena regionální chronologie. Katalog hodnocených keramických souborů byl publikován až v roce 1979 (Zápotocký 1979). Je jen škoda, že obě části - vlastní text a katalog - nebyly spojeny do jedné celistvé monografie.

Na př́istupy M. Zápotockého navázal na počátku 80. let prakticky pouze F. Gabriel, který podobnou metodiku aplikoval na středověkou keramiku z hradů v severních Čechách, kde sledoval vztahy mezi entitami (objekty) a kvalitami keramiky (technologie, morfologie okrajů a výzdoba) prostřednictvím Šerova algoritmu podobnosti. Sledované znaky (okraje a výzdoba) byly uspořádány pomocí maximálních koster grafu a vytvořené sekvence (vývojové řady keramiky - okrajů a červeně malované výzdoby) byly interpretovány v chronologickém smyslu a validovány především pomocí písemných pramenů vztahujících se $\mathrm{k}$ jednotlivým hradům (Gabriel-Smetana 1983). Práce archeologa F. Gabriela a historika J. Smetany však překročila i regionální rámec studia, nebot' se zabývala rovněž původem a otázkou distribuce světlé oxidační keramiky s červeným malováním v Čechách, na jejímž rozšíření v severních Čechách se podílelo významné hrnčířské pracoviště v České Lípě (Gabriel-Smetana 1983, 129-133).

Slibný rozvoj statistických metod v 70. letech byl vystř́́dán u některých badatelů patrnou skepsí, nebot' často naráželi na objektivní nedostatek kvalitních pramenů, které by umožnily použití těchto metod s menšími problémy (srov. Smetánka 1974, 481). Problematické byly i limitující možnosti počítačového zpracování velkého množství alfanumerických dat - tehdy například děrnoštítkové metody.

V období 70.-80. let byly také podrobně rozvíjeny deskripční systémy středověké keramiky či tzv. keramické kódy, kdy jednotlivé znaky na keramice byly rozdělovány do jednotlivých skupin, typů a variant a často označované numerickými kódy (typickým př́íkladem je právě Středověká keramika ze severočeského Polabi - Zápotocký 1979). Deskripční systémy umožňovaly statistické zpracování a vyhodnocení početných keramických znaků. Jiné numerické kódované systémy vznikaly primárně pro potřeby katalogového zpracování a muzejní evidence, jako např́íklad systém Museum vytvořený pro středověkou keramiku z Tábora a Sezimova Ústí ${ }^{5}$ (Drda-Krajíc 1983).

$\mathrm{Z}$ metodického hlediska došlo $\mathrm{k}$ určitému progresu $\mathrm{v}$ deskripci keramiky - poprvé byla keramika klasifikována podle keramických tříd. První, kdo u nás studoval keramické třídy, byl Z. Smetánka v 70. letech, který k popisu keramických tř́íd pozdně hradištní keramiky využil barvu,

5 Tento systém byl v roce 1997 inovován, tak aby obsahoval nejen metodu základního tř́idění materiálu, ale i možnosti statistických přehledů a různých úrovní tiskových výstupů, včetně grafů (Krajíc a kol. 1998, 166). 
hrubost ostřiva a kvalitu výpalu (Smetánka 1973, 467-468). Deskripce keramických tříd (skupin) se také uplatnila při zpracování mostecké středověké keramiky (Klápště-Velímský 1975, 653).

Pozornost byla $\mathrm{v} 70$. a 80 . letech věnována publikaci keramických souborů z prostředí středověkých měst, $\mathrm{v}$ menší míře také z hradů a dalších opevněných sídel.

V tomto období bylo publikováno několik monografií o středověké keramice. Ještě tradiční typologickou metodou byly zpracovány nálezy keramiky ze studní v Plzni ze Solní ulice (Nechvátal 1976). Problémem bylo, že zpracování keramiky vycházelo z výzkumů studní, které byly zkoumány $\mathrm{v}$ rámci sanace plzeňského podzemí, a nebyla u nich vždy sledována stratigrafie výplní. Nebylo tak možné sledovat jejich synchronizaci s tvarovým a typologickým vývojem keramických nádob. $Z$ interpretačního hlediska byla důležitá př́ípadová studie o středověké studni z Mostu, v níž byl větší důraz kladen na rozbor stratigrafie výplně, který částečně osvětlil i proces zaplňování těchto typů objektů (Klápště 1983). U mimořádně dochovaných dřevěných konstrukcí mosteckých studní a jímek byly také poprvé využity metody prrírodovědného datování pomocí dendrochronologie (Velímský 1977; Kyncl 1977; 1983).

Na počátku 80. let publikoval M. Richter vlivnou monografii zhodnocující dlouholetý výzkum Hradišt'ka u Davle - Sekanky (1982). Rozsáhlý prostor (téměř 100 stran!) je věnován středověké keramice. Hradišt'ko-Sekanka představuje klíčovou lokalitu pro studium keramiky 13. století, nebot' se zde společně vyskytují jak starší „hradištni““ prvky na keramice, tak prvky vyspělého hrnčířství označované jako „kolonizačni“", které jsou spojeny především s pronikáním světlé oxidační keramiky s červeným malováním a s nástupem nových tvarů keramiky (konvice, džbány, zvonovité misko-poklice). $\mathrm{V}$ publikaci byl kladen důraz na prezentaci celých tvarů pocházejících z klíčových nálezových situací, především z výplní zahloubených staveb, na nichž byla postavena interpretace lokality. Zvláštní pozornost byla věnována technologii keramiky, kterou až na výjimky dosavadní práce o středověké keramice v Čechách pomíjely (včetně petrografických rozborů). Studium technologických stop na keramice přineslo důležité poznatky týkající se způsobů vytváření nádob (profilující obtáčení) a jejich výpalu. Velký prostor byl věnován hrnčířským značkám na dnech nádob a jejich kulturně-historické interpretaci. Význam Richterovy práce spočíval i v tom, že prostřednictvím technologie výroby a hrnčířských značek byly řešeny ekonomické otázky týkající se zásobování sídliště keramikou s různých hrnčířských dílen. Kapitoly o středověké keramice v monografii o Sekance snesou přísná měřítka i vzhledem k zahraničnímu bádání. Po metodické, ale i interpretační stránce vycházel M. Richter především ze starších prací německých (W. Hübener, W. Janssen, U. Lobbedey) a polských archeologů (J. Kruppé, B. Lepówna, Z. Kołos-Szafrańska) a etnografů (W. Hołubowicz).

Kromě užitkové keramiky pokračovalo bádání i v oblasti kamnářské keramiky. Ve druhé polovině 80. let publikoval první studie o pozdně středověkých kachlích MUDr. Z. Hazlbauer v časopise Archaeologia historica; jeho výzkum přinesl mnohé důležité poznatky týkající se umělecké stránky výroby kachlů a interpretace reliéfních motivů (1986). Navázal tak na starší práce Z. Smetánky (1968; 1969b) nebo J. Richterové (1982). Jeho mimořádná publikační aktivita pokračovala i v následujících letech.

Koncem 80. let se z historické archeologie začala postupně vydělovat archeologie postmedievální zabývající se obdobím přelomu 15./16. až konce 18. století. Základní otázky a přístupy tohoto mladého odvětví archeologie formuloval Z. Smetánka společně s J. Žegklitzem v Československém časopise historickém (Smetánka-Žegklitz 1989) a ve sborníku Studies of Post-Medieval Archaeology (Smetánka-Žegklitz 1990). V řadě oblastí kopíroval vývoj postmedievální a novověké archeologie vývoj archeologie středověké.

\section{Devadesátá léta - kontextuální fáze a hledání nových perspektiv studia středověké keramiky}

$\mathrm{V}$ 90. letech došlo $\mathrm{k}$ určitému útlumu $\mathrm{v}$ počtu publikací věnovaných speciálně stř̌edověké keramice. Příčinu lze spatřovat $\mathrm{v}$ odklonu od zpracovávání středověké keramiky z velkých systematických výzkumů. Pozornost archeologů se od počátku 90. let soustředila na provádění 
záchranných a předstihových výzkumů, především v jádrech historických měst, při nichž byly získávány početné nálezy keramiky, které však nebylo možné z časových a kapacitních, či jinak méně objektivních důvodů rychle zpracovávat a zveřejňovat. Často docházelo pouze k rychlému elementárnímu hodnocení keramiky pro datování archeologických situací, nebo k charakteristice základních horizontů. Popis a hodnocení keramiky byly často redukovány na doplněk k nálezovým zprávám bez ambicí na komplexní zpracování, v němž by byly řešeny širší výzkumné otázky nebo samotná interpretace archeologických kontextů. Drtivá většina tehdy získaných a zpracovaných souborů keramiky ze záchranných a předstihových výzkumů se stala definitivně součástí „,̌̌edé literatury“ (doplněk nálezových zpráv). Pouze menší množství nálezů stř̌edověké keramiky bylo publikováno.

S pádem komunistického režimu v roce 1989 nastal př́liv nových impulsů díky snadnější dostupnosti zahraniční literatury a obnoveným kontaktům s archeologickými pracovišti v západní Evropě, což se pozitivně odrazilo v nových tématech a př́istupech studia vrcholně a pozdně středověké keramiky. Pod vlivem urbánní archeologie a zahraničních, zejména anglosaských prací (Orton-Tyers-Vince 1993) byl větší důraz kladen nejen na keramiku samotnou, ale i na detailní poznání nálezového prostředí - archeologický kontext. Na základě vztahu keramických nálezů ke kontextu jejich užití je možné dále rozvíjet další kontextuální souvislosti, například technologické, sociální, ekonomické apod. Proto můžeme období 90. let označit za období kontextuálni fáze studia středověké keramiky.

Klíčovým oborovým problémem ve výzkumu středověké keramiky se stal původ keramiky v různých nálezových situacích a otázky týkající se reprezentativnosti keramických souborů pro datování. V této souvislosti lze vyzdvihnout metodický př́íspěvek L. Hrdličky zabývající se pražskou středověkou keramikou 11. až 13. století, v němž autor poukázal na komplikované zacházení $\mathrm{s}$ odpadem $\mathrm{v}$ prostředí vrcholně středověkého města a podceňování post-depozičních procesů při podrobné evaluaci vybraných středověkých kontextů. Metodický př́íspěvek vycházel z detailních znalostí specifik pražského prostředí a stratifikace. Vyzdvihl především význam krátkodobě utvářených terénních situací - tenkých vrstev postupně a plynule narůstajících a shora uzavřených, které jsou zdrojem keramiky sice nečetné, ale zato kvalitní, vzhledem k vývoji keramické sekvence, především díky kvalitativně novým prvkům, zejména okrajům (Hrdlička 1993).

V druhé polovině 90 . let byla také otevřena diskuse nad dalšími tématy a směřování studia keramiky. Na počátku roku 1997 se uskutečnilo mezioborové kolokvium Keramika jako archeologický pramen, jehož cílem byl kromě bilance stavu výzkumu keramiky v Čechách také rozvoj dalších diskusí nad metodickými otázkami studia (články z této konference byly publikovány v prvním čísle padesátého ročníku Archeologických rozhledů v roce 1998; shrnutí Salač 1998, 7-15). Na tomto kolokviu zazněly dva medievistické příspěvky od J. Klápště (1998) a P. Vařeky (1998), kteří nastínili řadu nových otázek a témat, které ovlivnily další směřování studia keramiky. Zároveň se jedná o dva odlišné přístupy ke keramice mladšího středověku.

Článek J. Klápště charakterizuje kulturně-historické pojetí studia keramiky, ale obohacené i o sociálně-ekonomické otázky, spojené především s problematikou 13. století - obdobím středověké transformace (Klápště 1994). Keramika byla považována za jeden z nositelů kulturních a sociálně-ekonomických změn, projevující se změnami ve výrobní a spotřební sfére, například v nahrazování tradiční „hradištní“ keramiky postupně se prosazující světlou oxidační nebo redukční keramikou a novými tvary nádob - konvice, džbány, zvonovité misky/poklice, nádoby se čtyřlaločnatým ústím (Klápště 1998; 1997). ${ }^{6}$ Jejich rozšíření bylo kladeno do souvislosti s rozvojem městského tržního hospodářství a s příchodem nových obyvatel z německých zemí. Tyto systémové a kulturní změny společnosti ovlivnily tradiční hradištní ráz výroby keramiky - upozorněno bylo na to, že keramické výrobky však zpravidla nenesou sociální a etnickou indikaci:

6 Obdobně se o historické a kulturní změně uvažovalo u nástupu keramiky raně novověké na přelomu 15. a 16. století, projevující se zejména ve tvarech nádob, rozšiřující sortiment užitkové keramiky a umožňující dokonalejší př́ípravu pokrmů a konzumaci, např. trojnohých pánví, mělkých mís, talírủ apod. (Krajíc a kol. 1998, 181). 
„In Anbetracht der Wirkung des Marktmechanismus kann die Erscheinung einer neuen Ware weder als sozialer noch als etnischer Indikator bewertet werden“" (Klápště 1998, 151).

Nová témata studia keramiky mladšího středověku navrhl ve více metodickém článku P. Vařeka $(1998,123)$. Témata byla již dřive představena v Archeologickém fóru $\mathrm{v}$ roce 1995 (BřeňKašpar-Vařeka 1995, 37-38). Za hlavní okruhy otázek považoval uvedený autor technologii výroby, kulturní, sociální a ekonomický kontext a nálezový kontext, které v sobě zahrnují celou řadu subtémat. Mezi subtémata technologie výroby středověké keramiky zahrnul poznání př́írodních zdrojů surovin a jejich exploatace, úrovně a možnosti výroby, hrnčířského řemesla a trhu. Kulturní a sociální kontext zahrnuje analýzu tvarů a metrických vlastností za účelem poznání jejich funkce, dále př́pravu a úpravu pokrmů, výživu a stolování. Ekonomický kontext je zaměřen na otázky týkající se směny, obchodu, pohybu zboží apod. Konečně nálezový kontext umožňuje studium mechanismů vzniku stratigrafických jednotek (formační a post-depoziční procesy), zacházení s odpadem a vzorce chování odrážející se v prostorové distribuci keramických zlomků.

Ve zmiňovaných tématech lze spatřovat jak vlivy procesuální archeologie projevující se ve větším důrazu na poznání procesů týkajících se výroby (operační řetězec), ekonomiky (tržní mechanismy) a zacházení s odpadem (formační a post-depoziční procesy), tak vliv postprocesualismu projevující se v důrazu na studium funkce a významu keramiky ve společnosti v kontextu různého sociálního prostředí. Přes snahu o vymezení širokého okruhu otázek se bádání o středověké keramice upínalo zpravidla pouze $\mathrm{k}$ některému ze zmiňovaných témat a žádná komplexně pojatá práce zohledňující všechny zmiňované otázky dosud v českém prostředí nevznikla.

Jedním z klíčových témat studia keramiky mladšího středověku bylo poznání charakteru její distribuce a regionalizace, a to prostřednictvím studia distribučních okruhů (Klápště 1998; Vařeka 1998; Ernée-Vařeka 1998). Obecně byla regionalizace keramiky, výrazně se projevující od 9./10. až 13. století, kladena do souvislosti s rozšířením lokální výroby orientované na regionální trhy: „(...) značná regionální roztřištěnost projevující se množstvím distribučních okruhů odlišného keramického zboži naznačuje, že se výroba keramiky soustředěná ve venkovských centrech či preurbánnich aglomeracich orientovala na úzce lokální trhy, které nebyly zapojeny do rozsáhlejšího tržního systému (...)“(Vařeka 1998, 132).

V 90. letech došlo $\mathrm{k}$ významnému nárůstu počtu získaných a hodnocených keramických souborů, především z výzkumů historických jader měst, na jejichž základě mohly být lépe popsány jednotlivé keramické okruhy, např. jihočeské a západočeské šedé redukční keramiky, severočeské světlé tvrdě pálené oxidační keramiky, středočeské a východočeské hrubé středně tvrdě pálené keramiky i s geografickými hranicemi (obr. 6; Vařeka 1998, 128-132, obr. 1).

V 90. letech byly propracovávány také nové metody deskripce keramiky. Větší důraz byl kladen především na makroskopickou deskripci keramických tř́íd členěných podle britských fabric. Propracovávána byla také podrobná typologizace okrajů a výzdoby, přičemž pro jednotlivé skupiny, typy a varianty byly vytvářeny podrobné alfanumericky kódované systémy, které umožňovaly statistické zpracování a komparaci keramických souborů pocházejících z různých středověkých lokalit (Břeň-Kašpar-Vařeka 1995; Vařeka 1998; Nováček 2000).

Období 90. let charakterizuje především rychlý nástup počítačového zpracování keramiky. V této době byly vytvořeny první verze databázových programů v SW Paradox, dBase, později MS Access umožňující počítačové zpracování značného množství keramických dat (obr. 7). V Čechách se nejrozšířenějším databázovým systémem stal Klasifik, později inovovaný v Keramik, prostřednictvím něhož byla zpracována řada keramických souborů z jižních a středních Čech včetně Prahy především z výzkumů společnosti Archaia Praha a Ústavu archeologické památkové péče středních Čech (Vařeka 1998). Pro západní Čechy se hlavním stal databázový systém Klasiker, využívaný při zpracovávání středověké keramiky z výzkumů společnosti ZIP, o. p. s., nebo Západočeského muzea, jeho předností byla i online verze publikovaných typářư (Nováček-Tetour 2000).

7 Viz http://www.zip-ops.cz/keramikaonline/. 


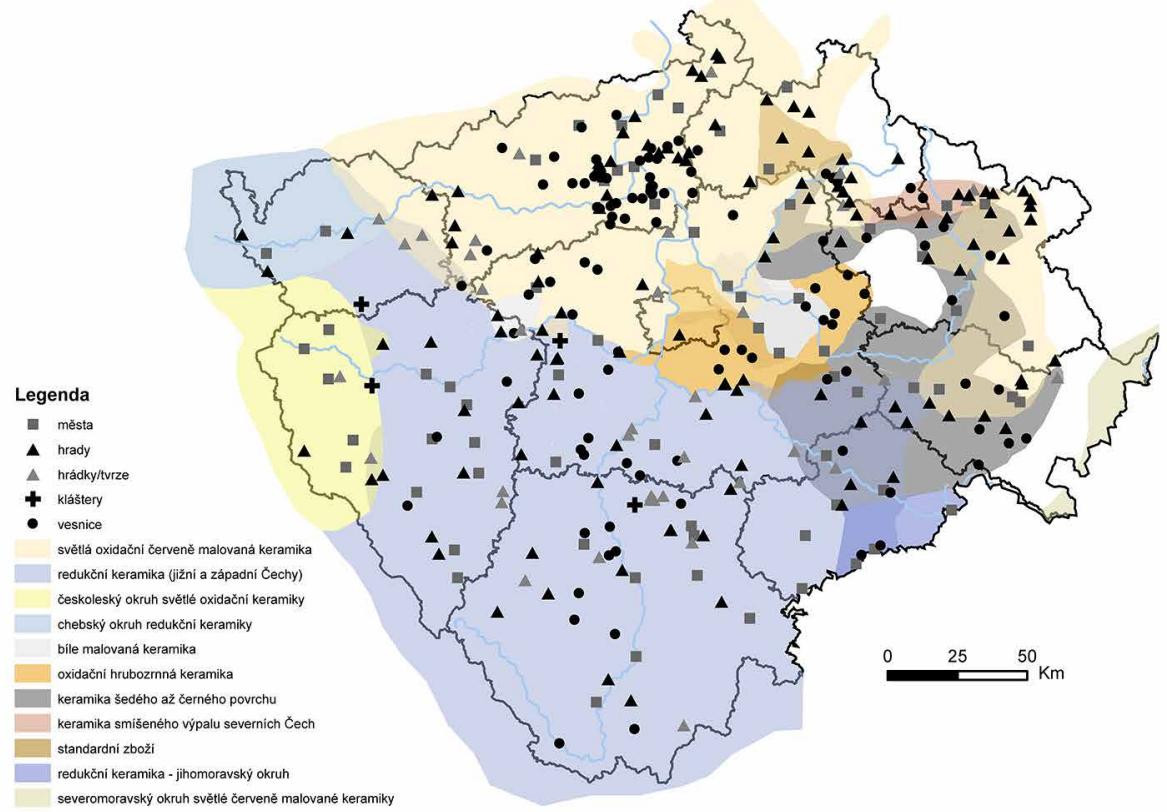

Obr. 6. Grafické znázornění výskytu hlavních keramických skupin rámcově ze 14. až 15. století s jejich orientačními hranicemi na základě informací o skladbě keramických tř́íd z publikovaných keramických souborů ze středověkých lokalit. Vytvořil L. Čapek.

Abb. 6. Grafische Veranschaulichung des Vorkommens der grob aus dem 14. bis 15. Jahrhundert stammenden Hauptkeramikgruppen mit ihren ungefähren Grenzen anhand der aus veröffentlichten Keramikkomplexen von mittelalterlichen Fundstätten stammenden Informationen über die Zusammensetzung der Keramikklassen. Zusammengestellt von L. Čapek.

Koncem 90. let se také více rozšiřily datovací možnosti především na základě užší spolupráce s prrírodovědnými obory. Jako opora pro absolutní datování stř̌edověké keramiky byla využívána zejména dendrochronologie prostřednictvím spolupráce s inženýry J. a T. Kynclovými, která díky postupně vytvářeným dendrochronologickým standardům zároveň ukázala na rozpory v datování konstrukcí objektů a v datování na základě keramiky samotné (viz příklad mostecké studny 1/80). Jako neprůkazné se v důsledku četných intruzí v městských stratifikacích ukázalo datování na základě nejmladšího stř̌epu zastoupeného v souboru (Klápště-Kyncl-Kyncl 2000).

\section{První dvě dekády 21. století - pokračující kontextuální přrístup, interdisciplinární pojetí}

Přelom 20. a 21. století a první dvě dekády 21. století jsou ve znamení pokračujícího kontextuálního studia keramiky, kdy je přikládán velký důraz na kontextuální nálezové souvislosti konkrétních souborů keramiky. V centru pozornosti od konce 90 . let a na počátku nového tisíciletí stojí nálezy stř̌edověké keramiky z prostorově určených a shora uzavřených kontextů zejména odpadních jímek a studní (Krajíc a kol. 1998; Šmejda 1999; Frolík-Tomášek 2003; Pícka-Hůrková-Schneiderwinklová 2009; Orna a kol. 2011). Na rozdíl od předchozího bádání je podrobněji studována stratigrafie výplní (Cymbalak-Matějková 2012; Frolík-KozákováMusil 2018). 


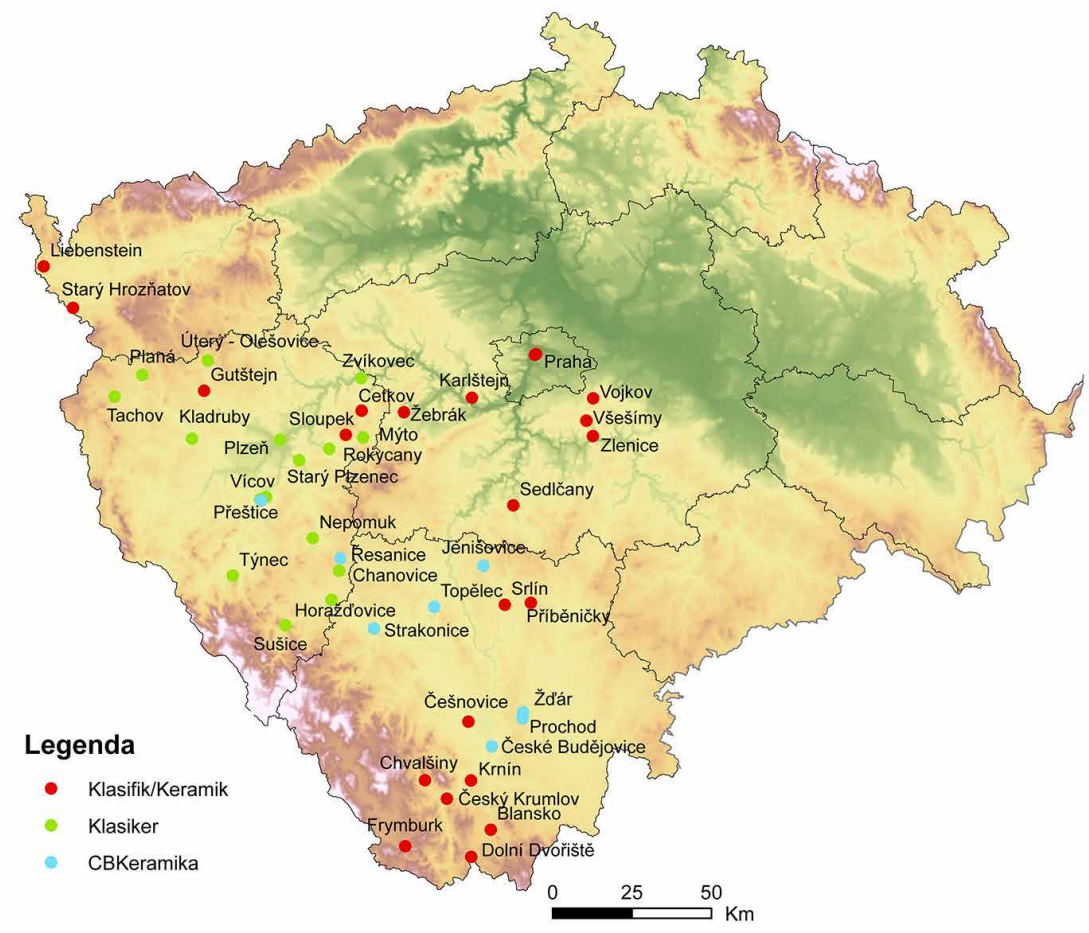

Obr. 7. Přehled zpracovaných souborů středověké keramiky v databázových systémech Klasifik/Keramik a Klasiker. Doplněn o databázový systém CBkeramika. Vytvořil L. Čapek.

Abb. 7. Übersicht der bearbeiteten mittelalterlichen Keramikkomplexe in den Datenbanksystemen Klasifik/Keramik und Klasiker. Ergänzt um das Datenbanksystem CBkeramika. Zusammengestellt von L. Čapek.

Na rozboru středověké keramiky z odpadních jímek byla postavena zásadní publikace o středověké keramice z domu čp. 226 v Mostě (Klápště a kol. 2002). Chronologie mostecké keramiky byla založena na synchronizaci vývoje typů nádob ve vztahu ke sledu vrstev výplní odpadních jímek. V některých př́ípadech bylo možné datování keramiky napojit na série získaných dendrodat z výdřevy konstrukcí jímek. Při rozboru středověké keramiky z odpadních jímek se ukázaly nápadné rozdíly ve skladbě současných keramických souborů, které bylo možné vysvětlit různými mechanismy zacházení s odpadem na městských parcelách.

Monografie o mostecké keramice dobře ilustruje práci se středověkými keramickými soubory a metodickými obtížemi spojenými s rozdílnou výpovědní hodnotou nálezových situací ze středověkých měst (k obecné problematice viz Vencl 2001). Situaci dobře popisuje $\mathrm{v}$ recenzi na knihu Z. Smetánka: „Většinou jsme se u lokalit městského charakteru, zejména v jejich staršich vývojových fázich, zatím setkávali a budeme setkávat při chronologické práci s postupným nárůstem vrstev a s vytvářením souvrství, o jejichžjednoduše chápané hodnotě pro studium chronologie, předevšim keramiky, se diskutuje a pochybuje. Nemáme však, a nebudeme mit jinou možnost než zkoušet hledat nové způsoby, jak s takovými i s dalšimi potenciálně chronologicky ,neurčitými ‘ nálezovými situacemi a z nich ziskanými středověkými soubory při hledáni její vnitřni detailnějši chronologie zacházet. Znamená to neustále vědět a nezapomínat, že pracujeme stále se soubory (vzorky) vysoce pravděpodobně smíšenými, které mohou být zatiženy fatální chronologickou 
chybou. Také zde bude nejspiš pro středověké obdobi platit, že jedině individuálni kontextuální posuzováni konkrétnich nálezových situaci a neustálé vylučováni těch nejistých, byt' sebeslibněji vypadajicich souborů je nezbytnosti.“" (Smetánka 2004, 449).

Monografie o mostecké keramice $\mathrm{z}$ domu čp. 226 byla založena na hodnocení celých tvarů $\mathrm{z}$ odpadních jímek, nebot' na nich lze nejlépe a nejkomplexněji nastínit proměnu tvarového keramického inventáře v čase a jejich kulturní a sociálni aspekty. Kapitoly o keramice byly zaměřeny především na definování vůdčích keramických typů a široce pojatých technologických skupin na základě několika markantních znaků. Opomenuto bylo vyhodnocení fragmentární keramiky z vrstev a výplní jiných typů objektů, jejich kvantifikace a statistické zpracování (s důrazem na studium okrajů a keramických tříd) se staly standardem zpracování velkých souborů keramiky z městských výzkumů (srov. Procházka 2004, 464-465). Přes výhrady k některým metodickým postupům se práce právem řadí mezi přední monografie o středověké keramice $\mathrm{z}$ oblasti severozápadních Čech.

Vedle studia objemových proporcí nádob byl kladen větší důraz na poznání jejich funkce, a to prostřednictvím u nás dosud ojedinělých analýz potravinových zbytků (Machovič-Novotná 2002). Součástí práce byl petrografický rozbor vybraných technologických skupin keramiky. Upozorněno bylo také na jisté poznávací limity makroskopického studia keramických tř́id zlomkové keramiky z blíže neurčených částí nádob, které bylo doloženo petrografickými analýzami (Hanykýř-Maryška-Brůček 2002).

Na počátku 21. století se objevily první práce, které se zabývaly kvantitativním hodnocením keramických nálezů z různých typů nálezových kontextů, které měly ukázat rozdíly ve struktuře složení keramiky vzniklé $\mathrm{v}$ důsledku formačních a post-depozičních procesů a odlišného způsobu nakládání s odpadem. Zásluhou K. Nováčka bylo upozornění na problematiku intruzí ve středověkých souvrstvích, respektive jejich správného rozlišování na reziduální a infiltrovanou keramiku (podle britských studií o keramice), jež byly na př́ikladu výzkumu středověké parcely domu čp. 186 v Plzni studovány prostřednictvím indexů diverzity, resp. heterogenity (Nováček 2003).

Období počátku 21. století charakterizuje důraz na formalizované deskriptivní a analyticko-syntetické postupy, tj. důsledné dodržování základních postupů v rámci archeologické metody, které „(...) nejenže část tohoto procesu objektivizuji, ale po téměr čtyřiceti letech postupné adaptace pro potřeby archeologie jsou již natolik stabilním a rozvinutým nástrojem, že dokonale vyhovuji povaze archeologických dat a umožňuji interaktivní a otevřenou práci s nimi (...)“ (Nováček a kol. 2010, 302).

Část archeologů mladšího středověku z okruhu plzeňské katedry archeologie se v metodách keramického výzkumu vrcholně a pozdně středověké keramiky inspirovala metodickými pracemi z oblasti pravěké a raně středověké archeologie (např. Neustupný 1997; 1998; Salač 1997; Macháček 2001). Od počátku 21. století začaly být více využívány vícerozměrové statistické metody pro studium struktur keramických souborů, a to nejen za účelem tvorby chronologie, ale i pro pochopení mechanismů vzniku keramických souborů v souvislosti s formačními a post-depozičními procesy. $\mathrm{V}$ archeologii mladšího středověku se jedná především o statistické metody, které umožňují studium vztahů a korelací mezi stratigrafickými a keramickými daty. Vedle tradiční explorační metody seriace se uplatňují také statistické vícerozměrové metody jako korespondenční, shluková a faktorová analýza (Vařeka 2002; Nováček a kol. 2010; Čapek-Militký a kol. 2016; Čapek 2018).

Na přelomu 90. let a počátku 21. století pozorujeme jistou skepsi mezi badateli vztahující se k makroskopickému určování keramických tříd, jejich tř́ídění a popis jsou ovlivněny řadou subjektivních faktorů (již např. Klápště a kol. 2002, 10). Objevují se proto snahy spojovat keramické třídy do větších celků, tzv. keramických skupin (podle německého systému třídění na tzv. Ware), na základě jednotné technologie, nebo hlavního markantního znaku, jejichž smyslem je lépe charakterizovat celkové proměny hrnčířské výroby (Vařeka 2002, 231; Klápště a kol. 2002, 15; Matějková 2014, 92-93). 
V prvních dvou dekádách 21. století je možné pozorovat soustavnější zájem o technologické otázky výroby keramiky, které se více přiblížily středoevropskému pojetí studia keramiky v Německu (např. Lüdtke-Schitzel 2001), Rakousku (Hofer et al. 2010) a Polsku (Rzeźnik 1995). Určitý přelom v chápání vývoje technologie utváření keramiky od dosud nejinspirativnější práce M. Richtera (1982) znamenala studie T. Bernhardta, která upozornila na možné techniky tváření středověké keramiky na hrnčiřských kruzích, včetně užití různých druhů podsýpek. Experimentálně bylo potvrzeno užití techniky vytáčení nádob s podsýpanými dny ještě v 15 . století (Bernhardt 2011, 67-75). Zároveň začaly být soustavně studovány primární a technologické stopy na středověké keramice, které byly ověřovány i prostřednictvím experimentálního výzkumu (Čapek a kol. 2018).

Nové impulsy ve studiu technologie výroby středověké keramiky přinesly intenzivnější kontakty s prŕrodovědnými disciplínami - zejména s petrografí́ -, které ukázaly rovněž i na jisté poznávací limity makroskopického studia keramických tříd. Již delší dobu se rozvíjela spolupráce s doc. Ing. V. Hanykýřem, DrSc., z pracoviště Ústavu skla a keramiky při Vysoké škole chemicko-technologické v Praze. Z petrografických metod byly poprvé u středověké keramiky využity mikroskopické analýzy tenkých výbrusů, analýzy nasákavosti nebo rentgenografické analýzy (Hanykýř-Maryška-Brůček 2002; Hanykýř-Nováček 2010). Na práci V. Hanykýře v současnosti navazuje doc. Ing. A. Kloužková, Ph.D. (Kloužková-Zemanová-Frolík-Svobodová 2014). Metodickým problémem při aplikaci petrografických analýz se ukázal poznatek, že z analýzy stejného vzorku pocházejícího z jedné nádoby provedené nezávisle dvěma laboratořemi mohou vzejít rozdílné výsledky (Matějková-Stoksik 2011; Matějková 2014, 93-96).

V novém tisíciletí se také kromě petrografie rozvíjely dosud málo rozšířené analýzy usazenin (potravinových zbytků) na středověkých nádobách pomocí infračervené nebo hmotnostní spektroskopie (Machovič-Novotná 2002) či pomocí testů na specifické protilátky využívající komerční sady kitů na potravinové alergeny (Pavelka-Vařeka 2008; Pavelka-Orna 2011). Tyto metody umožňují poznání funkce nádob v souvislosti s přípravou, konzumací a uchováváním pokrmů.

Kromě užitkové keramiky nadále pokračoval soustavný zájem i o výzkum kamnářské a stavební keramiky. Ve většině případů se publikace držely tradičního typologického schématu (Brych 2004; Krajíc 2005) a až na výjimky se nezabývaly komplexnějšími otázkami týkajícími se technologie výroby (Ernée-Hanykýř-Maryška 2004; Ernée 2008; Krajíc 2008) nebo kulturně-historickými otázkami souvisejícími s kulturou bydlení (např. Havlice-Kypta a kol. 2017).

\section{Problémy současného výzkumu keramiky v Čechách}

Keramika jako nejrozšířenější artefakt středověku má ústřední úlohu nejen pro datování archeologických kontextů, ale i pro jejich samotnou interpretaci. Navzdory tomu však středověká keramika stojí dnes poněkud stranou odborného zájmu v Čechách, o čemž svědčí zaznamenaná nízká publikační aktivita. Představuje, na rozdíl od jiných artefaktů např́ílad ze skla a kovů, utilitární předmět s nízkou ekonomickou tržní hodnotou, který není př́liš atraktivní pro prezentaci, má hodnotu jen pro samotné badatele zabývající se keramikou. Problematická je i úroveň publikací o středověké keramice, která je značně kvalitativně nevyvážená. Publikace o středověké keramice jsou často v článcích a studiích redukovány na základní hodnocení keramiky, které slouží jako „doplněk“ k vlastnímu rozboru archeologických terénních situací a především pro podporu jejich datování. Chybí tradice „materiálově“ zaměřených publikací, které by vycházely v edičních řadách a jež by zpř́stupňovaly výsledky detailního keramického výzkumu. V tomto směru je mnohem dál německé a polské bádání o středověké keramice. V řadě českých publikaci chybí snaha o komplexnější pojetí studia, které by řešilo konkrétní teoretické sociálně-ekonomické a kulturně-historické otázky.

České (do jisté míry to platí i pro moravské) bádání o středověké keramice se potýká s řadou metodických problémů, které nejsou dostatečně oborově řešeny, a když ano, pak jen v rámci interních diskusí. 
Jedním z palčivých problémů je prohlubující se propast mezi množstvím archeologických terénních výzkumů a stavem post-exkavačního analyticko-syntetického zpracování získaných artefaktů, včetně keramiky (k obecnému problému vyhodnocování terénních výzkumů viz Procházka 2013, 47-51). Dochází tak často k velkému časovému odstupu od terénní části výzkumu a vlastního post-exkavačního zpracování a vyhodnocení keramiky, což má negativní důsledek v postupné ztrátě informační hodnoty, kterou lze označit jako archeologickou transformaci sensu stricto (Neustupný 2007, 64). Dnes je nutné se smířit s představou, že středověká keramika z některých velkých systematických, ale i menších záchranných a předstihových výzkumů nebude zpracována a zveřejněna vůbec, nebo jen výběrově v omezeném množství s důrazem na klíčové soubory z nálezových situací. Jako př́íklad lze zmínit dlouholetý systematický výzkum jedné z nejvýznamnějších lokalit pozdního středověku - Sezimova Ústí, z nějž se podařilo publikovat alespoň základní keramické horizonty (Richter-Krajíc 2001, 157-163), ovšem komplexního zpracování v podobě monografie o sezimovoústecké středověké keramice a hrnčířství se zřejmě již nedočkáme, nebot' její zpracování přesahuje možnosti jedné instituce.

Řešením „stavu nezpracovanosti“ středověké keramiky je úzká a týmová spolupráce pracovišt' zabývajících se terénním výzkumem s univerzitním prostředím, které vedle možností získávání nejrůznějších grantů a stipendií pro podporu základního a aplikovaného výzkumu disponuje dostatečným odborným a personálním zázemím a stálým potenciálem v př́livu studentů, kteří mohou být vtaženi do procesu zpracovávání a vyhodnocování keramických souborů v rámci bakalářského a magisterského studia pod teoretickým a metodickým vedením kvalifikovaných školitelů (k tomu např. Procházka 2013, 48-49). Nejvíce specialistů zabývajících se středověkou keramikou a obecně archeologií mladšího středověku v Čechách působí v současnosti na univerzitách (Praha, Plzeň, České Budějovice, Hradec Králové). Na těchto univerzitách jsou vedeny přednášky a semináře ze stř̌edověké archeologie, v nichž je věnován prostor výuce oboru středověké keramiky. ${ }^{8}$ Řada specialistů zabývajících se výzkumem vrcholně středověké keramiky jako jednou z řady profesionálních činností působí také na jiných archeologických pracovištích a institucích v České republice (tab. 1). Př́znivý vývoj lze naopak spatřovat v dalších aktivitách,

Tab. 1. Přehled zastoupení badatelů-specialistů podle archeologických institucí a dosaženého vzdělání, kteří aktivně publikují příspěvky ke stř̌edověké keramice v domácích a zahraničních periodikách.

Tab. 1. Übersicht der Forscher-Experten nach archäologischen Institutionen und ihrer erreichten Ausbildung, die in in- und ausländischen Periodika aktiv Beiträge zur mittelalterlichen Keramik veröffentlichen.

\begin{tabular}{|c|c|c|c|c|c|c|c|c|c|c|c|c|}
\hline & \multicolumn{4}{|c|}{ Raný středověk } & \multicolumn{4}{|c|}{ Vrcholný a pozdní středověk } & \multicolumn{4}{|c|}{ Raný novověk } \\
\hline Instituce & Profesor & Docent & Ph.D. & Mgr. & Profesor & Docent & Ph.D. & Mgr. & Profesor & Docent & Ph.D. & Mgr. \\
\hline Univerzity & 1 & & 1 & 1 & 3 & 3 & 6 & 2 & 2 & 1 & 2 & 1 \\
\hline $\begin{array}{l}\text { Archeologické } \\
\text { ústavy AV ČR }\end{array}$ & 1 & & 9 & 1 & & 1 & & & & & 1 & \\
\hline $\begin{array}{l}\text { Národní památkové } \\
\text { ústavy }\end{array}$ & & & 1 & & & & & 1 & & & & \\
\hline Muzea & & & & & & & 2 & 6 & & & 1 & 2 \\
\hline $\begin{array}{l}\text { Neziskové } \\
\text { organizace }\end{array}$ & & & & & & & & 2 & & & 1 & 1 \\
\hline $\mathrm{Na}$ „,volné noze““ & & & & & & & & & & & 2 & \\
\hline Celkem & 2 & & 11 & 2 & 3 & 4 & 8 & 11 & 2 & 1 & 7 & 3 \\
\hline
\end{tabular}

$8 \mathrm{Na}$ Katedře archeologie Západočeské univerzity je výuce středověké keramiky věnován prostor v rámci povinných kurzů bakalářského studia archeologie středověku a novověku (AST3 a AST4), zruba čtyři dvouhodinové přednášky, doplněné o praktická čtyřhodinová cvičení. Větší prostor je výuce středověké keramiky věnován na Archeologickém ústavu Jihočeské univerzity (1 semestr v rozsahu 14 hodinových přednášek, včetně seminární výuky). 
které jsou spojeny s výzkumem středověké keramiky (workshopy, konference) a slouží i jako podpora pro vzdělávání mladých badatelů. ${ }^{9}$

V současné době je zaznamenán téměř na všech univerzitních pracovištích soustavný pokles počtu studentů oborů archeologie a negativně se projevuje také velká roztříštěnost výzkumných témat. O studium materiální kultury (včetně keramiky) je mezi studenty archeologie vzhledem $\mathrm{k}$ velkým metodickým nárokům na průpravu, ale i z časových důvodů na vypracování kvalitní kvalifikační práce poměrně malý zájem, o čemž svědčí nízký počet obhájených bakalářských a diplomových prací o středověké keramice. $Z$ výše uvedených důvodů není možné očekávat ve studentských pracích zásadní krok ve zveřejňování keramických souborů z dosud nezpracovaných středověkých výzkumů.

V tomto směru je slibnější vývoj na Moravě, kde jsou na Ústavu archeologie a muzeologie Filozofické fakulty Masarykovy univerzity cíleně zadávána témata zaměřená na zpracovávání a vyhodnocování středověké keramiky, která pochází z předstihových a záchranných výzkumů, např. společnosti Archaia Brno, Ústavu archeologické památkové péče a dalších archeologických institucí působících na Moravě. Význam těchto prací, byt' řada z nich nebyla publikována, nelze z vědeckého hlediska považovat za zanedbatelný (viz Procházka 2013, 49).

Jiným problémem je rozrůzněná úroveň poznání středověké keramiky v rámci regionů. V některých oblastech Čech není dosud dostatečně propracována relativní regionální chronologie keramiky (jižní Čechy - Jindřichohradecko, Strakonicko, Pošumaví, západní a severozápadní Čechy - Karlovarsko, Loketsko, střední Čechy - Podblanicko, Sedlčansko, severní Čechy Liberecko, Pokrkonoší, východní Čechy - Jaroměřsko, Novobydžovsko, okolí Poličky a České Třebové), a to především proto, že dosud nebyly z těchto regionů získány, zpracovány a publikovány důležité srovnávací keramické soubory, nebo se badatelé působící především v regionálních muzeích středověké keramice systematicky, nebo ani okrajově nevěnují. Jedná se většinou o kontaktní oblasti na česko-moravském pomezí a poblíž hranic se sousedními zeměmi (Bavorsko, Horní Franky, Sasko, Horní Rakousko, Lužice, Dolní Slezsko). Na druhé straně výrazně lepší není ani situace stavu výzkumu keramiky na druhé straně hranice v okolních státech.

Co se týče otázek spojených s výrobou keramiky, stále je nedostatečná úroveň poznání technologie středověké keramiky včetně primárních výrobních zařízení - hrnčířských pecí (Varadzin 2010; Čapek-Preusz 2019; na Moravě pak Procházka 2015). Dosavadní poznatky tak vychází ze starších výzkumů a antikvovaných studií, v nichž se opakuje řada omylů týkajících se např́íklad tvarování keramiky na hrnčířských kruzích (viz nesprávně používané obtáčení keramiky), což zároveň ukazuje, že málo archeologů je obeznámeno v detailu s technikami výroby keramiky (srov. např. Štajnochr 1998; Orna a kol. 2011). I když se od konce 90. let slibně rozvíjela spolupráce s prrírodovědnými obory, zejména s petrografií zásluhou V. Hanykýřre, stále jsou metody a výsledky petrografického výzkumu v bádání o keramice málo využívány. V tomto směru významný progres učinilo moravské bádání, které více rozvinulo jak studium petrografie středověké keramiky, které řeší i otázky provenience a distribuce surovin (např. Gregerová-Procházka 1998; 2007; Gregerová a kol. 2010; Procházka-Hložek 2013), tak vlastní experimentální výzkumy zaměřené na technologii výroby keramiky (Bočková a kol. 2013).

Problémem výzkumu středověké keramiky je, že neexistují obecně přijatelné zásady deskripce středověké keramiky, napříč badateli a institucemi panuje velká individualita v př́ístupech. Existuje řada různých „osobních“ př́stupů k deskripci keramiky, které často vycházejí z vlastních empirických poznatků (ke kritice např. Hrdlička 1993, 109). Panují také nejasnosti v terminologii mladší stř̌edověké keramiky a nebyly doposud učiněny pokusy o její sjednocení, jako např́íklad u raně středověké keramiky (Boháčová 1995; Bubeník-Frolík 1995). Samostatnou kapitolou je otázka publikací a zveřejňování výsledků keramického výzkumu, kde panuje také značná nejednotnost ve výběru kresebné nebo fotograficky dokumentované keramiky a v úrovni její grafické prezentace (k problémům např. Tomková 1993). V publikacích také často postrádáme

9 Zmínit lze například workshopy a konference pořádané Ústavem archeologie a muzeologie Filozofické fakulty Masarykovy univerzity v Brně. 
např́iklad kvantifikaci znaků, která by umožnila alespoň elementární srovnávání mezi soubory $\mathrm{z}$ různých lokalit.

Řešením je nalezení společného oborového konsensu mezi badateli a vypracování minimálních standardů ve výzkumu středověké keramiky, podobných těm, které byly zveřejněny v řadě západoevropských zemí (Bauer et al. 1986; Orton-Tyers-Vince 1993; MPRG 1998; Lüdtke-Schnitzel 2001; Hofer et al. 2010). Tento stav je také dán tím, že v Čechách nepůsobí fungující pracovní skupina pro výzkum středověké keramiky, např po vzoru M.P.R.G. - Medieval Pottery Research Group (založena ve Velké Británii v roce 1975) nebo Internationaler Arbeitskreis für Keramikforschung (založen v Německu v roce 1983), která by usměrňovala výzkum středověké keramiky a poskytovala diskusní platformu pro výměnu informací mezi badateli - specialisty zabývajícími se středověkou keramikou. Skupina pro výzkum středověké keramiky při České společnosti archeologické, založená v polovině 90 . let P. Vařekou a K. Nováčkem, již dlouhodobě žádnou činnost nevykazuje.

Středověká archeologie v Čechách málo sleduje pohyby v současném výzkumu středověké keramiky v zahraničí, kde se dnes rozvíjí řada nových teoretických př́ístupů v oblasti zkoumání materiální kultury středověku. Důležitost interpretační stránky bádání o stř̌edověké keramice pro studium středověké kultury a každodenního života je u nás velmi podceňována a interpretace vychází tradičně z kulturně-historických schémat. Kromě již dlouhodobého zájmu o ekonomické otázky spojené s obchodem a distribucí keramiky prostřednictvím tržních systémů (např. Verhaeghe 1983; Davey-Hodges 1983; Gaimster 1993) jsou ve výzkumu středověké keramiky a obecně materiální kultury stále více prosazovány teorie z oblasti sociologie, sociální a kulturní antropologie, vycházející z prací vlivných sociologů, jako jsou B. Latour (teorie sítě aktérů - Actor-Network Analysis) a P. Bourdieu (koncept habitu), nebo antropologů A. Appaduraie a I. Kopytoffa (biografie předmětů) a M. B. Schiffera (relační př́istupy, spotřební chování - konzumerismus) či prací postprocesuálních archeologů M. Shankse (symetrická archeologie, fenomenologie) a I. Hoddera (reflexivní a symbolická archeologie). Na středověkou keramiku je nahlíženo jako na element spojující sociální vztahy mezi lidmi, prostředím, krajinou, prostorem a architekturou (tzv. entanglement). Zároveň jsou na keramice studovány znaky, které mohou ukazovat na sociální a kulturní identitu tvůrců a uživatelů (srov. Jervis 2014 s přehledem literatury).

Ukazuje se, že i přes pozitivní rozvoj, který nastal po změně režimu po roce 1989, stojí česká archeologie stále poněkud stranou zahraničního bádání a současného teoretického diskurzu.

\section{Závěr}

Studium keramiky vrcholného a pozdního středověku lze rozdělit celkem do pěti vývojových etap či fází, které dobře vystihují tehdejší převládající teoretické otázky, přístupy a metody, které byly formovány jak soudobými archeologickými paradigmaty, tak ideovými až ideologickými názory předních badatelů a kontakty s příbuznými obory - historií, etnografií, dějinami umění a architektury -, přičemž později přibyly i přírodovědné metody (petrografie, dendrochronologie). Vývoj studia můžeme dobře sledovat na základě analýzy publikovaných studií o keramice a důležitých monografií, které ukazují, že v obecných trendech následují vývoj keramického výzkumu v celoevropském měřítku, byt' s poněkud odlišnou časovou trajektorií, což bylo způsobeno i omezenými kontakty se zahraničními badateli a literaturou vinou komunistického režimu trvajícího více než čtyřiceti let.

Konec 19. a počátek 20. století lze charakterizovat jako starožitnické období, kdy středověká keramika byla na okraji zájmu etnografů, kteří se primárně zabývali umělecko-historicky „hodnotnější“ novověkou keramikou. Na přelomu 19. a 20. století byly postupně zveřejňovány informace ze záchranných amatérských archeologických výzkumů, které přinesly první nálezové soubory keramiky.

Za skutečné počátky studia mladší středověké keramiky lze považovat začátek 50 . let, kdy došlo k postupné profilaci a institucionalizaci historické archeologie. Toto období můžeme 
označit za typologickou fázi, nebot' byly poprvé definovány základní keramické tvary a typy nádob. Počátek systematického zájmu o středověkou keramiku se soustředil i z jistých ideologických důvodů na keramiku husitského období a především na hledání datovacích opor pro absolutní chronologii, kdy byl důraz kladen zejména na depoty mincí v keramických nádobách nebo na soubory keramiky pocházející z nálezových situací „absolutně“ datovaných písemnými prameny. Postupně se také propracovávala relativní chronologie využívající tzv. eliminační metodu. V 50. a 60. let docházelo k postupné standardizaci deskripce keramiky a její grafické prezentaci. Zdroje inspirací byly především čerpány z německé a polské literatury, zde hlavně otázky týkající se technologie výroby.

V 70. letech je možné pozorovat ve studiích o středověké keramice zřetelný odraz procesuálního paradigmatu, který je patrný zejména v osvojení přístupů formalizované deskripce, kvantifikace keramiky a statistického testování, které proniklo do několika prací. Větší důraz byl kladen na formalizaci postupů, precizování terminologie a vytváření deskripčních systémů umožňujících zpracování velkého množství keramických dat získávaných prostřrednictvím velkých systematických, ale i záchranných archeologických výzkumů. V 80. letech můžeme pozorovat pokles v počtu studií o keramice, který nelze jednoduše vysvětlit jinak než postupným odkládáním problému zpracovávání keramických souborů z velkých systematických a záchranných výzkumů.

Pád komunistického režimu po roce 1989 a období 90 . let přineslo nové impulsy a témata ve studiu středověké keramiky, především díky obnoveným kontaktům se zahraničním bádáním. Větší pozornost byla upřena $\mathrm{k}$ analýzám nálezového prostředí keramiky - archeologickým kontextům kdy bylo upozorňováno na značné rozdíly ve struktuře složení keramiky způsobené vlivem řady formačních a post-depozičních procesů. Proto toto období můžeme označit jako kontextuální, kdy větší důraz byl kladen nejen na kvalitu nálezových kontextů, ale také na jejich samotnou interpretaci. Otevřela se rovněž řada nových témat keramického výzkumu zaměřených na technologii keramiky a sociálně-ekonomické otázky spojené s hrnčířskou výrobou, obchodem a distribucí keramiky. Slibný rozvoj v poznání technologie výroby keramiky nastal díky spolupráci s př́rodovědnými obory (zejména petrografií) a $\mathrm{v}$ př́ípadě datování $\mathrm{s}$ dendrochronologií. Česká archeologie středověku si po vzoru prací z oblasti pravěké archeologie osvojila způsoby formalizované deskripce a databázového zpracování včetně statistického vyhodnocení keramických dat pomocí vícerozměrových metod.

Přestože dnes dochází k patrnému rozvoji v keramickém výzkumu, stále se potýkáme s řadou problémů, z nichž nejzávažnější lze spatřovat ve stavu nezpracovanosti řady velkých archeologických výzkumů. Za mimořádně důležité lze považovat vytvoření oborových standardů deskripce keramiky, včetně sjednocení terminologie, které by umožnilo širší srovnávací studium a řešení komplexnějších otázek spojených s výrobou středověké keramiky, její organizací a distribucí.

Studie je výstupem projektu NAKI II - Vrcholně středověká keramika jako součást movitého kulturního dědictví, č. projektu DG18P02OVV020.

\section{Literatura}

BAREŠ, F., 1901: Nádobí staré domácnosti v Mladé Boleslavi, ČL X, 21.

BAUER, I. et al., 1986: Leitfaden zur Keramikbeschreibung (Mittelalter - Neuzeit). Terminologie - Typologie - Technologie. München.

BERNHARDT, T., 2011: Exkurz II: Experimentální ověření možnosti výroby podsýpané keramiky na rychle rotujícím kruhu. In: Orna, J. a kol., Keramická produkce města Plzně v období 14. a 15. století, 67-75. Plzeň.

BOČKOVÁ, Z. a kol., 2013: Bočková, Z.-Doležalová, K.-Kochan, Š.-Mazáčková, J.-Slavíček, K.-Těsnohlídek, J., Experimentální výroba keramiky v Panské Lhotě, AH 39, 119-137.

BOHÁČOVÁ, I., 1995: Möglichkeiten und Grenzen eines allgemeinen Konsenses aus dem Gebiet des Studiums frühmittelalterlicher Keramik - Terminologie, Themen, verschiedene Ebenen des Erkenntisprozesses 
- zu den Schlüssen aus der Diskussion auf dem 2. Keramischen Kolloquium in Mikulčice. In: Slawische Keramik in Mitteleuropa vom 8. bis zum 11. Jahrhundert. Terminologie und Beschreibung (Poláček, L., ed.), 119-126. Brno.

BORKOVSKÝ, I., 1946: Nález skleněného poháru s arabským nápisem na Pražském hradě, ČSPS LIV, 136-139.

- 1953: Kostel Panny Marie na Pražském hradě, PA XLIV, 129-198.

- 1959: Výzkumy v Černé věži na Pražském hradě, PA L, 257-324.

- 1962: Opyš Pražského hradu, PA LIII, 381-454.

BÖHM, J., 1951: K otázce o vzniku feudalismu v českých zemích, ČL VII-VIII, 162-180.

BRYCH, V., 2004: Kachle doby gotické, renesanční a raně barokní. Výběrový katalog Národního muzea v Praze. Praha.

BŘEŇ, J.-KAŠPAR, V.-VAŘEKA, P., 1995: K problematice počítačového zpracování středověké keramiky (databáze KLASIFIK), Archeologické fórum 4, 36-41.

BUBENÍK, J.-FROLÍK, J., 1995: Zussamenfassung der Diskussion zur gemeinsamen Terminologie der grundlegenden keramischen Begriffe. In: Slawische Keramik in Mitteleuropa vom 8. bis zum 11. Jahrhundert. Terminologie und Beschreibung (Poláček, L., ed.), 128-130. Brno.

CLARKE, D., 1968: Analytical Archaeology. London.

CYMBALAK, T.-MATĚJKOVÁ, K., 2012: Zpracování nálezů ze dvou odpadních jímek a úskalí jejich interpretace, Staletá Praha XVIII, č. 2, 41-76.

ČERMÁK, K., 1896-1897: Hrnčírny v Čáslavi ze XIV., XV. a XVI. věku. Zpráva Muzejního spolku Včela čáslavská za rok 1897-1898, 7-16. Čáslav.

- 1897: Hrnčíŕi v Čáslavi a jejich a památky, PA XVII, 213-224.

- 1906: Památky z hradu Lichnice, PA XXI, 143-146.

- 1906a: Dlaždice a jiné starožitnosti z hradu Paběnic, z Hrádku v Čáslavi a z Vlaského dvora v Kutné Hoře, PA XXI, 231-234.

ČERNOHORSKÝ, K., 1952: Keramika a feudalismus, ČL XXXIX, 223-230.

- 1953: Keramika a feudalismus, ČL XL, 21-31.

ČAPEK, L., 2018: Archeologický výzkum na nádvoří radnice v Českých Budějovicích. Analýza a syntéza stratigrafických a keramických dat a interpretace behaviorálního modelu, AR LXX, 596-649.

ČAPEK, L.-MILITKÝ, J. a kol., 2016: Historická radnice v Českých Budějovicích ve světle archeologických výzkumů a rozboru hmotných pramenů. Plzeň - České Budějovice.

ČAPEK, L.-PREUSZ, M., 2019: Středověké a novověké hrnčířské pece v Čechách - kritické zhodnocení výpovědních možností studia - Mittelalterliche und neuzeitliche Töpferöfen in Böhmen - eine kritische Auswertung der Aussagemöglichkeiten von Studien, AH 44, 313-355.

ČAPEK, L. a kol., 2018: Čapek, L.-Těsnohlídková, K.-Slavíček, K.-Všianský, D.-Pracný, P., Technologie výroby a archeometrické studium středověké keramiky. Plzeň - Brno.

DAVEY, P.-HODGES, R., 1983: Ceramics and Trade: A Critique of the Archaeological Evidence. In: Ceramics and Trade (Davey, P.-Hodges, R., edd.), 1-16. Sheffield.

DENKSTEIN, V., 1953: O úkolech historické archeologie, ČNM A CXXII, 219-223.

DOLEŽALOVÁ, K., 2015: Výzkum vrcholně a pozdně středověké keramiky na území České republiky se zaměřením na deskripční systémy a třídění keramiky podle technologie výroby, Acta FF ZČU 7, č. 2, 39-66.

DRDA, M.-KRAJÍC, R., 1983: K metodice tř́iění středověké keramiky na Táborsku - Klassifizierungsmethodik der keramischen Funde aus der Gegend von Tábor, AH 8, 175-187.

DROBNÁ, Z., 1951: Husitské památky v našich zemích, ČNM A CXX, 89-106.

- 1953: Skromné řemeslo: Několik poznámek ke keramice 14.-16. století, ČL XL, 76-83.

DROBNÁ, Z. (red.), 1963: Středověká keramika v Československu. Výstava v Národním Muzeu v Praze, květen 1962 - červen 1963. Praha.

DURDÍK, T., 1980: K chronologii keramiky 14.- počátku 15. století ve východní části středních Čech - Zur Chronologie der Keramik des 14. - bis Anfang des 15. Jahrhunderts im Ostteil Mittelböhmens, AH 5, 361-368.

ERNÉE, M., 2008: Gotické kamnové kachle z hradu a zámku v Českém Krumlově. Archeologické výzkumy v Jižních Čechách - Supplementum 5. České Budějovice - Praha. 
ERNÉE, M.-VǍ̌EKA, P., 1998: Die Graphittonkeramik des 13. Jahrhunderts in Südböhmen und Prag. In: Frühmittelalterliche Graphittonkeramik in Mitteleuropa. Naturwissenschaftliche Untersuchungen, Internationale Tagungen in Mikulčice IV (Poláček, L., ed.), 219-230. Brno.

ERNÉE, M.-HANYKÝŘ, V.-MARYŠKA, M., 2004: Výsledky př́rodovědných analýz gotických kachlových kamen z Českého Krumlova, PA XCV, 175-222.

FLORIAN, Č., 1914: Nález historické keramiky v Chrudimi, PA XXVI, 67-69.

FROLÍK, J.-TOMÁŠEK, M., 2003: Soubor pozdně středověké keramiky z výplně zaniklé studny č. p. 108 v Kutné Hoře, ASČ 7, 735-758.

FROLÍK, J.-KOZÁKOVÁ, R.-MUSIL, J., 2018: Jímky 938 z Chrudimi - Hradební ulice, pokus o určení statutu jejího majitele - Abwassergrube 938 in Chrudim - Hradební-Straße: Versuch einer Statusbestimmung ihres Besitzers, AH 43, 455-489.

GABRIEL, F.-SMETANA, J., 1983: K vývoji výrobních okruhů červeně malované keramiky v severních Čechách - Zur Entwicklung der Produktionsbereiche rot gemalter Keramik in Nordböhmen, AH 8, 119-138.

GAIMSTER, R. M. D., 1993: Cross-Channel ceramic trade in the Middle Ages: Archaeological evidence from the spread of Hanseatic culture to Britain. In: Archäologie des Mittelalters un Bauforschung im Hanseraum. Eine Festschrift für Günter P. Fehring. Schrifften des Kulturhistorischen Museums in Rostock (Gläser, M., ed.), 251-260. Rostock.

GREGEROVÁ, M. a kol., 2010: Petroarcheologie keramiky v historické minulosti Moravy a Slezska. Brno.

GREGEROVÁ, M.-PROCHÁZKA, R., 1998: Erste Ergebnisse naturwissenchaftlicher Untersuchungen an Graphittonkeramik aus Brno. In: Frühmittelalterliche Graphittonkeramik in Mitteleuropa. Naturwissenschaftliche Untersuchungen, Internationale Tagungen in Mikulčice IV (Poláček, L., ed.), 275-278. Brno.

- 2007: Exkurz: K současnému stavu petrografického výzkumu brněnské keramiky 12.-13. století ve vztahu $\mathrm{k}$ distribuci surovin, PV 48, 271-299.

HANYKÝŘ, V.-MARYŠKA, M.-BRU゚ČEK, P., 2002: Hodnocení mikrostruktury a fázového složení keramiky z Mostu. In: Archeologie středověkého domu v Mostě (čp. 226). Mediaevalia archaeologica 4 (Klápště, J., ed.), 35-76. Praha - Most.

HANYKÝŘ, V.-NOVÁČEK, K., 2010: Př́iloha VIII. Rozbor a hodnocení kuchyňské a stolní keramiky a její srovnání s pálenou keramickou krytinou. CD příloha. In: Nováček, K. a kol., Kladrubský klášter 1115-1421. Osídlení - architektura - artefakty, 1-35. Plzeň.

HAVLICE, J.-KYPTA, J. a kol., 2017: Gotické kachle z Jindřichova Hradce. České Budějovice.

HAZLBAUER, Z., 1986: Př́íspěvek k technologii výroby pozdně středověkých reliéfních kachlů - Beitrag zur Technologie der spätmittelalterlichen Reliefkacheln, AH 11, 489-504.

HEJNA, A., 1954: Archeologický výzkum v Př́běnicích, ČNM CXXIII, 157-162.

- 1956: Archeologický výzkum románské klášterní basiliky v Teplicích, AR VIII, 171-176, 188-190, 294, 300-301.

- 1960: Výzkum středověké vesnice v Krašovicích u Sedlčan, AR XII, 537-550.

- 1962: Středověká stanice říční plavby v Červené nad Vltavou, AR XIV, 494-496, 501-510.

- 1964: Krašovice - př́íspěvek k výzkumu středověké vesnice v Čechách, PA LV, 178-221.

- 1966: Středověká vesnická keramika v Čechách (K některým otázkám starší středověké keramiky z vesnických sídlišt’ v Čechách), SbNM A XX, 313-363.

- 1967: Slohová kritéria v datování české středověké keramiky, ČNM CXXIII, 177-183.

HOFER, N., ed., 2010: Handbuch zur Terminologie der mittelalterlichen und neuzeitlichen Keramik in Österreich. Wien.

HOŁUBOWICZ, W., 1950: Garncarstwo wiejskie zachodnich terenów Białorusi. Toruń.

HRDLIČKA, L., 1967: Středověká hrnčířská pec s keramickou klenbou v Bakově nad Jizerou, AR XIX, 511-524.

- 1993: Poznámky k chronologii pražské středověké keramiky, AR XLV, 93-112.

HRDLIČKA, L.-RICHTER, M.-SMETÁNKA, Z., 1966: Výzkumy v Sezimově Ústí v r. 1965, AR XVIII, $662-680$.

JANSSEN, W., 1966: Zur Typologie und Chronologie mittelalterlicher Keramik aus Südniedersachsen. Neumünster. 
JERVIS, B., 2014: Pottery and Social Life in Medieval England. Towards of Relational Approach. Oxford - Philadephia.

KAVÁN, J., 1956: Hradišt'ko u Davle, AR VIII, 377-386.

KLÁPŠTĚ, J., 1978: Středověké osídlení Černokostelecka, PA LXIX, 423-475.

- 1983: Studie o středověké studni z Mostu, PA LXXIV, 443-492.

- 1994: Změna - středověká transformace a její předpoklady. In: PA - Supplementum 2. Mediaevalia Archaeologica Bohemica 1993, 9-59. Praha.

- 1997: Proměny keramiky ve středověkém Mostě, Archaeologia Historica Polona V, 163-174.

- 1998: Die Anfänge der jüngeren mittelalterlichen Keramik in Böhmen als kulturhistorisches Problem, AR L, 138-158.

- 2016: The Archaeology of Prague and the Medieval Czech Lands, 1100-1600. Sheffield - Bristol.

KLÁPŠTĚ, J. a kol., 2002: Archeologie středověkého domu v Mostě (čp. 226). Mediaevalia archaeologica 4. Praha.

KLÁPŠTĚ, J.-VELÍMSKÝ, T., 1975: Příspěvek ke studiu počátků města Mostu, AR XXVII, 651-672.

KLÁPŠTĚ, J.-KYNCL, J.-KYNCL, T., 2000: Dendrochronologie mostecké studny 1/80 a předpoklady objektivní archeologické datace, AR LII, 681-689.

KLOUŽKOVÁ, A.-ZEMENOVÁ, P.-FROLÍK, J.-SVOBODOVÁ, L., 2014: Hodnocení středověké keramiky z Lažan u Chrudimi pomocí analýz XRF, XRD, OM, DSC-TG a RS - Beurteilung der mittelalterlichen Keramik aus Lažany bei Chrudim anhand der RFA, Röntgendiffraktion, optischen Mikroskopie, DSC-TG und der Raman-Spektroskopie, AH 39, 75-87.

KOULA, J., 1888: Příspěvky k historii hrnčířství v Čechách, zvl. otisk ze Zlaté Prahy r. IV. Praha.

- 1908: Příspěvek k dějinám české keramiky, PA XXII, 235-240.

KRAJÍC, R. a kol., 1998: Dům pasíře Prokopa v Táboře (Archeologický výzkum odpadní jímky v domě čp. 220). Tábor.

- 2005: Středověké kamnářství. Výzdobné motivy na gotických kachlích z Táborska. Tábor.

- 2008: Středověké cihlářství. Sezimovo Ústí - archeologie středověkého poddanského města 4. České Budějovice - Tábor.

KRUPPÉ, J., 1961: Studia nad ceramiką XIV wieku ze Starego Miasta w Warszawie. Warszawa.

- 1967: Garncarstwo warszawskie w wiekach XIV i XV. Wrocław - Warszawa - Kraków.

KYNCL, J., 1977: Př́íspěvek k metodice dendrochronologie (Standardizace a synchronizace letokruhových křivek s využitím regresní analýzy a korelací) - Zur Methodik der Dendrochronologie, AH 2, 317-330.

- 1983: Dendrochronologie studny 1/80 v Mostě, PA LXXIV, 507-517.

LEMINGER, E., 1903: Zpráva o nálezu starožitných výrobků hrnčířských v Kutné Hoře, PA XX, 65.

LIŠKA, A., 1943: Hrnčiřrské a kamnářské památky v Museu hl. m. Prahy. In: Zprávy České keramické společnosti XX, 1-23. Praha.

LÖBBEDEY, U., 1968: Untersuchungen mittelalterlicher Keramik vornehmlich aus Südwestdeutschland. Berlin.

LÖWENHÖFER, J., 1912: Nálezy uprostřed města Budějovic r. 1909. In: Výroční zpráva musejního spolku, 18-29. České Budějovice.

LÜDTKE, H.-SCHNITZEL, K. et al., 2001: Handbuch zur mittelalterlichen Keramik in Nordeuropa. Schriften des archäologischen Landesmuseums. Bd. 6. Neumünster.

MACHÁČEK, J., 2001: Studie k velkomoravské keramice. Metody, analýzy a syntézy, modely. Brno.

MACHOVIČ, V.-NOVOTNÁ, M., 2002: Analýza usazenin na středověkých nádobách z Mostu infračervenou spektroskopií. In: Archeologie středověkého domu v Mostě (čp. 226). Mediaevalia archaeologica 4 (Klápště, J., ed.), 77-92. Praha - Most.

MATĚJKOVÁ, K., 2014: Keramický sortiment turnovských domácností. Možnosti zpracování keramických souborů z městských souvrství - Das Keramiksortiment aus den Turnauer Haushalten. Bearbeitungsmöglichkeiten der aus Stadtschichten stammenden Keramikkollektionen, AH 39, 89-119.

MATĚJKOVÁ, K.-STOKSIK, H., 2011: Contribution of Scientific Analyses to the Archaeological Assessment of Pottery Production in Turnov, Czech Republic, Interdisciplinaria Archaeologica - Natural Sciences in Archaeology 2, 125-138. 
MPRG 1998: A Guide to the Classification of Medieval Ceramic Forms. MPRG Occasional Paper 1. London. NECHVÁTAL, B., 1965: Archeologický výzkum v Ervěnicích a problémy dalšího studia středověkých tvrzí v Čechách, AR XVII, 831-851.

- 1976: Středověká studna v Plzni - Solní ulici. In: Archeologické studijní materiály 12. Praha.

NEKUDA, V., 1970: Odpověd’ M. Richtrovi - Z. Smetánkovi, VVM XII, 123-124.

NEKUDA, V.-REICHERTOVÁ, K., 1968: Středověká keramika v Čechách a na Moravě. Brno.

NEUSTUPNÝ, E., 1997: Syntéza struktur formalizovanými metodami - vektorová syntéza. In: Počítačová podpora $v$ archeologii (Macháček, J., ed.), 237-258. Brno.

- 2007: Metoda archeologie. Plzeň.

- 1998: K variabilitě laténské keramiky, AR L, 77-94.

- 2017: Czech Archaeology Under Communism. In: Archaeology of the Communist Era (Lozny, E., ed.), 151-165. Cham.

NIEDERLE, L., 1921: Život starých Slovanů III/1. Praha.

NOVÁČEK, K., 2000: Středověký dům v Plzni. Archeologický výzkum parcely v Sedláčkově ulici 1. In: Sborník Západočeského muzea v Plzni - řada Historie 15, 5-66. Plzeň.

- 2003: Rezidualita v městských souvrstvích. In: Sedmdesát neústupných let. Sborník k životnímu jubileu prof. Evžena Neustupného (Šmejda, L.-Vařeka, P., edd.), 131-146. Plzeň.

NOVÁČEK, K. a kol., 2010: Kladrubský klášter 1115-1421. Osídlení - architektura - artefakty. Plzeň.

NOVÁČEK, K.-TETOUR, M., 2002: Možnosti využití databázových systémů pro zpracování keramického materiálu. Formalizovaná deskriptivní databáze KLASIKER, nestránkováno. Plzeň.

ORNA, J. a kol., 2011: Keramická produkce města Plzně v období 14. a 15. století. Plzeň.

ORTON, C.-HUGHES, M., 2013: Pottery in Archaeology. Second Edition. Cambridge.

ORTON, C.-TYERS, P.-VINCE, A., 1993: Pottery in Archaeology. Cambridge.

PAVELKA, J.-ORNA, J., 2011: Výsledky analýzy potravinových zbytků na pozdně středověké keramice z Plzně, Acta Fakulty filozofické Západočeské univerzity v Plzni, č. 3, 84-99.

PAVELKA, J.-VAŘEKA, P., 2008: Příspěvek k poznání středověké stravy ve vrcholném a pozdním středověku. První výsledky analýzy potravinových zbytků na keramice, Kuděj - Časopis pro kulturní dějiny 10, č. 1, 97-109.

PAVLŮ, I., 1971: Pražská keramika dvanáctého a třináctého století. Praha.

PAVLŮ, I.-PAVLŮ, I., 1971: Seriace nálezových souborů středověké keramiky. In: Nové archeologické metody I. Tř́íění materiálu, 122-129. Praha.

PÍCKA, J.-HŮRKOVÁ, J.-SCHNEIDERWINKLOVÁ, P., 2009: Odpadní jímky z Kašperských Hor - Abwassergruben aus Kašperské Hory (Bergreichenstein), AH 34, 103-159.

PROCHÁZKA, R., 2004: Jan Klápště ed.: Archeologie stř̌edověkého domu v Mostě (čp. 226). Mediaevalia archaeologica 4. Praha - Most 2002, AR LVI, 463-467.

- 2013: Záchrana archeologických památek na prahu 3. tisíciletí - věda, etika, obživa? In: Veřejná archeologie III. Př́spěvky z konferencí Archeologie a veřejnost 2006 a 2008 (Bureš, M.-Šmolíková, M., edd.), 35-55. Praha.

- 2015: Mittelalterliche Töpferöfen in Mähren. In: Den Töpfern auf der Spur Orte der Keramikherstellung im Licht der neuesten Forschung 46. Internationales Symposium Keramikforschung des Arbeitskreises für Keramikforschung und des Römisch-Germanischen Zentralmuseums Mainz vom 16. bis zum 20. September 2013 in Mayen (Grunwald, L., ed.), 215-224. Mainz.

PROCHÁZKA, R.-HLOŽEK, M., 2013: Opavský džbán v Brně? K otázce počátků vrcholně středověké keramiky, ČSM B 62, 231-244.

RADOMĚRSKÝ, P., 1963, Keramika datovaná mincemi. In: Středověká keramika v Československu, 32-38. Praha.

- 1964: Středověká keramika, Muzejní a vlastivědná práce 11/2, 70-85.

RADOMĚRSKÝ, P.-RICHTER, M., 1974: Korpus české keramiky datované mincemi, SbNM A XXVIII, 57-171.

REICHERTOVÁ, K., 1948: K vývoji stř̌edověké keramiky v Čechách, ZPP 8, 82-92.

- 1952: Výzkum středověké tvrze v Martinicích u Votic, AR IV, 417-421

- 1956: Př́íspěvek k datování středověké keramiky v Čechách, PA XLVII, 171-186. 
- 1955: K otázce červeně malované středověké keramiky. In: Referáty o pracovních výsledcích československých archeologů I, 159-164. Liblice.

- 1957: K metodickým otázkám studia středověké keramiky, AR IX, 566-568.

- 1959: Středověká keramika datovaná mincemi, PA L, 246-256.

- 1962: Středověká hrnčířská dílna v Hořovicích, AR XIV, 676, 704-705.

- 1965: Středověká keramika ze Sezimova Ústí, Tábora a Kozího hrádku. In: Archeologické studijní materiály III. Praha.

- 1971: Poznámky k metodice studia středověké keramiky, ČsČH XIX, 118-122.

RICHTER, M., 1957: Výsledky záchranného výzkumu na Sekance, k. o. Hradišt'ko. In: Referáty o pracovních výsledcích československých archeologů za rok 1956, 136-144. Liblice.

- 1959: Keramika z 12. až počátku 14. století v Čechách datovaná poklady mincí, ČNM CXXVIII, 4-22.

- 1961: Nejstarší středověká polévaná keramika v Čechách, PA LII, 573-579.

- 1963: Výzkum opevněné středověké osady v Hradišt'ku u Davle, AR XV, 200-219, 221-223.

- 1967: Hrnčířské pece v Kostelci nad Orlicí, AR XIX, 500-510.

- 1982: Hradišt'ko u Davle. Městečko ostrovského kláštera. Praha.

RICHTER, M.-HRDLIČKA, L., 1964: Výzkum v Sezimově Ústí v roce 1964, AR XVII, 655-668.

RICHTER, M.-KRAJÍC, R., 2001: Sezimovo Ústí - archeologie středověkého poddanského města. 2. Levobřežní předměstí - archeologický výzkum 1962-1988. Písek.

RICHTER, M.-SMETÁNKA, Z., 1958: Zur Datierung und Problematik der Anfänge der rotbemalten Keramik in Böhmen. In: Epitymbion R. Haken, 86-91. Praha.

- 1959: Př́íspěvek k metodice studia středověké keramiky v Čechách, AR XI, 86-97.

- 1970: Středověká keramika v Čechách a na Moravě, Nekuda V.-Reichertová, K. Recenze, ČČH 18, 90-93. RICHTEROVÁ, J., 1982: Středověké kachle. Praha.

RYBAKOV, A. B., 1948: Remeslo drevnej Rusi. Moskva.

RZEŹNIK, P., 1995: Ceramika naczyniowa z Ostrowa Tumskiego we Wrocławiu w X-XI wieku. Poznań.

SALAČ, V., 1998: Keramika jako archeologický pramen, AR L, 7-15.

- 1997: K využití seriace při datování sídlištní keramiky. In: Počítačová podpora v archeologii (Macháček, J., ed.), 215-235. Brno.

SCHEUFLER, V., 1963: Problémy lidovosti v keramice, ČL L, 35-40.

SMETÁNKA, Z., 1959: Středověká osada mezi Štíhlicemi a Kozojedy, AR XI, 683-691.

- 1962: Výzkum středověké osady v Bylanech u Kutné Hory, AR XIV, 159-160, 167-174.

- 1968: Technologie výroby českých kachlů od počátku 14. do počátku 16. století, PA LIX, 543-578.

- 1969: A. Hejna, Středověká vesnická keramika v Čechách, Sborník Národního Muzea A-20, 1966, 5, AR XXI, 399-402.

- 1969a: K morfologii českých středověkých kachlů, PA LX, 228-265.

- 1970: K aplikaci analytických metod ve středověké archeologii. In: Seminář ke středověké keramice, 34-35. Opava.

- 1973: Př́íspěvek k chronologické problematice pozdní doby hradištní, PA LXIV, 463-486.

- 1974: I. Pavlů, Pražská keramika 12. a 13. století, Praehistorica 4, Praha 1971, PA LXV, 480-481.

- 1977: P. Radoměrský-M. Richter, Korpus české středověké keramiky datované mincemi, Sborník Národního muzea v Praze A-28, PA LXVIII, 244-246.

- 1987: Hledání zmizelého věku. Sondy do středověkých Čech. Praha.

- 2004: Jan Klápště ed.: Archeologie středověkého domu v Mostě (čp. 226), AR LVI, 444-463.

- 2014: Dva domy v Jiřské ulici a jeden v podhradí. Ze vzpomínek a rozpomínek na proměny archeologie středověku. In: Středověká Evropa v pohybu. K poctě Jana Klápště, 503-521. Praha.

SMETÁNKA, Z.-RICHTER, M., 1958: Příspěvek k metodice studia středověké keramiky v Čechách. In: Referáty o pracovních výsledcích československých archeologů za rok 1957 (Böhm, J., ed.), 131-150. Liblice.

SMETÁNKA, Z.-TOPOLOVÁ, O., 1967: Die älteste böhmischen Keramik mit Zinn-Bleiglasur, PA LVIII, 499-544.

SMETÁNKA, Z.-RICHTER, M.-ŠPAČEK, L., 1964: Výzkum v Sezimově Ústí v r. 1962 a 1963, AR XVI, 691-696, 700-703, 705-716. 
SMETÁNKA, Z.-ŽEGKLITZ, J., 1989: Postmedievální archeologie v Čechách a její problémy, ČČH XXXVII, 728-738.

- 1990: Post-medieval archaeology in Bohemia and its problems. In: Studies in Post-Medieval archaeology 1, 7-22. Praha.

ŠIMEK, J., 1896: Zprávy o kutnohorských hrnčíríích, PA XVI, 654-662.

ŠMEJDA, L., 1999: K hmotné kultuře Vysokého Mýta ve středověku. In: Mediaevalia archaeologica 1 (Ježek, M.-Klápště, J., red.), 169-192. Praha.

ŠTORCH, E., 1927: Archeologické nálezy v Mostě, PA XXIX, 3.

ŠTAJNOCHR, V., 1998: Archaické technologie tváření keramiky, AR L, 95-105.

ŠTĚPÁNEK, M., 1971: Nejenom středověká keramika, ČsČH XIX, 122-128.

ŠVEHLA, J., 1901: Nádobí kuchyně a stolu staročeského. Droby k dějinám českého hrnčířství XIV. a XV. století, otisk výroční zprávy muzea táborského. Tábor.

- 1911: Nádoby s nápisy z Ústí Sezimova a Kozího Hrádku, ČSPSČ XIX, 9-14.

TOMKOVÁ, K., 1993: Ke studiu raně středověké keramiky, AR XLV, 113-126.

TUREK, R., 1948: České hradištní nálezy datované mincemi, Slavia Antiqua I, 487-535.

- 1948a: České denáry jako datovací pomůcka archeologická, Numismatické listy III, 1-2.

VARAZDIN, L., 2010: Hrnčířská výroba ve východní části středních Evropy 6.-13. století v archeologických pramenech, AR LXII, 17-71.

VAŘEKA, P., 1998: Proměny keramické produkce vrcholného a pozdního středověku v Čechách, AR L, 123-137.

- 2002: Keramika pozdního středověku až počátku novověku z areálu bývalých kasáren Jiřího z Poděbrad na náměstí Republiky v Praze 1 (zjištovací výzkum v letech 1998-1999), Archaeologica Pragensia 16, 217-249.

VELÍMSKÝ, T., 1977: K dendrochronologickému výzkumu středověkých nálezů z Mostu - Zur dendrochronologischen Untersuchung mittelalterlicher Funde aus Most, AH 2, 299-306.

VENCL, S., 2001: Souvislosti chápání pojmu „nálezový celek“v české archeologii, AR LIII, 592-614.

VERHAEGHE, F., 1983: Medieval pottery production in coastal Flanders. In: Ceramics and trade. The production and distribution of later medieval pottery in north-west Europe (Davey, P.-Hodges, R., edd.), 63-94. Sheffield.

WINTER, Z., 1906: Dějiny řemesel a obchodu v Čechách v XIV. a XV. století. Praha.

WOLF, O., 2005: Počátky středověkého osídlení na česko-slezském pomezí východně od Krkonoš (se zvláštním zřetelem k JV Podkrkonoší). Nepublikovaná diplomová práce na ÚAM FF MU v Brně.

ZÁPOTOCKÝ, M., 1978: Středověká keramika ze severočeského Polabí. Morfologie a relativní chronologie, PA LXIX, 171-238.

- 1979: Katalog středověké keramiky severočeského Polabí. Praha.

\section{Zusammenfassung}

Zum Studium der Keramik des Hoch- und Spätmittelalters in Böhmen - Themen, Methoden, Vorgehensweisen

Ziel des vorliegenden Beitrags ist eine Auswertung der Entwicklung der Untersuchung hoch- und spätmittelalterlicher Keramik in Böhmen und der Versuch einer kritischen Reflexion der bisherigen Entwicklung einschließlich der gegenwärtigen Untersuchung von Keramik. Die Entwicklung der Studien über mittelalterliche Keramik in Böhmen kopiert in den allgemeinen Trends die Entwicklung der ausländischen Erforschung von Keramik im gesamteuropäischen Maßstab. Für die objektive Auswertung der Entwicklung nach 1945 wurden die Analysen der in den führenden tschechischen Periodika Archeologické rozhledy (Archäologische Rundschau) und Archaeologica historica veröffentlichten Arbeiten über mittelalterliche Keramik herangezogen.

Das Studium der Keramik des Hoch- und Spätmittelalters lässt sich in fünf Entwicklungsphasen untergliedern, für welche spezielle theoretische Fragen, Vorgehensweisen und 
Methoden charakteristisch waren, die sowohl die zeitgenössischen archäologischen Paradigmata (kulturhistorische, prozessuale und postprozessuale), als auch die gedanklichen Ansätze und in den Anfängen des Studiums bis gar ideologischen Ansichten der führenden Forscher und die Kontakte zu den verwandten Fachbereichen - Geschichte, Ethnographie, Kunstgeschichte und Architektur - geformt haben. Später kamen noch naturwissenschaftliche Fachzweige hinzu (Petrographie, Dendrochronologie).

Das Ende des 19. und den Anfang des 20. Jahrhunderts kann man als antiquitäre Periode charakterisieren, als mittelalterliche Keramik sich am Rande des Interesses der Ethnographen befand, die sich primär mit der kunsthistorisch „wertvolleren“ Keramik der Neuzeit beschäftigten. An der Wende des 19. und Anfang des 20. Jahrhunderts wurden nach und nach Informationen aus amateurhaft durchgeführten archäologischen Rettungsgrabungen veröffentlicht, welche die ersten Fundkomplexe an Keramik erbrachten (Grabungen von K. Čermák, J. Švehla und einer Reihe weiterer).

Als tatsächliche Anfänge des Studiums jüngerer mittelalterlicher Keramik kann man die Anfänge der fünfziger Jahre des 20. Jahrhunderts betrachten, als es zu einer allmählichen Profilierung und Institutionalisierung des Fachzweigs Archäologie des jüngeren Mittelalters kam. Die Anfänge eines systematischen Interesses an der mittelalterlichen Keramik der Hussitenzeit können wir in den Arbeiten der Kunsthistorikerin Z. Drobná und insbesondere dann in den Arbeiten von K. Reichertová beobachten, welche die ersten methodischen Arbeiten über hoch- und spätmittelalterliche Keramik veröffentlichte. Diese Zeit können wir als typologische Phase bezeichnen, da die keramischen Grundformen und -typen von Gefäßen erstmals definiert wurden. Die Untersuchung mittelalterlicher Keramik konzentrierte sich vor allem auf die Suche nach qualitativ guten datierbaren Rückhalten für eine absolute Chronologie, als Hortmünzen in Keramikgefäßen oder Keramikkomplexen eine große Bedeutung beigemessen wurde, die aus anhand von schriftlichen Quellen ,absolut“ datierbaren Fundsituationen (Zeit der Gründung und des Untergangs eines Objekts) stammten. Nach und nach hat man auch Methoden zur Schaffung einer relativen Chronologie ausgearbeitet, welche die Prinzipien der sog. Eliminationsmethode zugrundelegten, die von Z. Smetánka und M. Richter 1958 auf einer Konferenz in Liblice vorgestellt und später auch publiziert wurden. In den sechziger Jahren kam es zu einer allmählichen Standardisierung der Beschreibung und Dokumentation mittelalterlicher Keramik und zur Präzisierung ihrer Terminologie. In jener Zeit wurden bei einer Reihe von systematischen und Rettungsgrabungen nach und nach neue Komplexe mittelalterlicher Keramik entdeckt, welche die bisherige Quellenbasis deutlich bereicherten.

In den siebziger Jahren kann in den Studien zur mittelalterlichen Keramik ein deutlicher Einfluss des aufkommenden prozessualen Paradigmas beobachten, der besonders in der Aneignung von Vorgehensweisen einer formalisierten Beschreibung, einer Methodik zur Probenentnahme und Quantifizierung von Keramik einschließlich statistischer Testverfahren zum Ausdruck kam. Eine größere Betonung wurde auf eine Formalisierung der Vorgehensweisen, eine Präzisierung der Terminologie und auf die Schaffung von deskriptiven Systemen gelegt, welche die Bearbeitung der großen Fülle keramischer Daten ermöglichte, die bei großen systematischen, aber auch bei Rettungsgrabungen entdeckt wurden. In den siebziger Jahren wurden erstmals auch regionale Keramiksequenzen geschaffen, die auf den Prinzipien der Eliminationsmethode basieren und statistische Vorgehensweisen nutzten - es handelte sich dabei besonders um Prager mittelalterliche Keramik, um Keramik aus dem nordböhmischen Elbland und aus Nordwestböhmen. In den achtziger Jahren können wir einen Rückgang an Keramikstudien beobachten, der sich nicht anders erklären lässt als das Resultat dessen, dass man das Problem, die aus großen systematischen und Rettungsgrabungen stammenden Keramikkommplexe zu bearbeiten, nach und nach aufgeschoben hat.

Der Fall des kommunistischen Regimes nach 1989 und die Zeit der neunziger Jahre brachte für das Studium mittelalterlicher Keramik neue Impulse und Themen, dies vor allem dank der wieder aufgenommenen Kontakte zur ausländischen Forschung. Die Studienthemen 
der Keramikforschung (kulturhistorische, prozessuale bis hin $\mathrm{zu}$ postprozessualen) wurden Ende 1997 von J. Klápště und P. Vařeka auf einem Keramikkolloquium in Prag vorgestellt. $\mathrm{Ab}$ den neunziger Jahren richtete man eine größere Aufmerksamkeit auf die Evaluierung der Fundumgebung von Keramik - auf die archäologischen Kontexte, als man auf die beträchtlichen, durch Formations- und postdepositäre Prozesse verursachten Unterschiede in der Struktur der Zusammensetzung der Keramik hinwies (Problematik von infiltrierter und Residualkeramik). Aus diesem Grund kann diese Zeit als kontextuell bezeichnet werden, als man nicht nur auf die Qualität der keramischen Fundkomplexe eine größere Betonung legte, sondern in Bezug auf den archäologischen Kontext ihrer Niederlegung auch auf ihre (sozialökonomische) Interpretation selbst. Es eröffnete sich auch eine Reihe neuer Themen der Keramikforschung, die auf Keramiktechnologien und auf mit der Töpferproduktion, dem Handel und Vertrieb von Keramik verbundene sozialökonomische Fragen ausgerichtet waren. Dank der Zusammenarbeit mit naturwissenschaftlichen Fächern (besonders mit der Petrographie) stellte sich in der Gewinnung von Erkenntnissen über Herstellungsverfahren von Keramik eine vielversprechende Entwicklung ein. Neue Möglichkeiten einer unabhängigen Datierung wurden durch die Dendrochronologie ermöglicht. Die tschechische Archäologie des Mittelalters hat sich nach dem Vorbild der Arbeiten aus dem Bereich der Archäologie der Vor- und Frühgeschichte Methoden einer formalisierten Beschreibung und datenbankmäßigen Bearbeitung zu eigen gemacht, einschließlich einer statistischen Auswertung keramischer Daten mittels explorativer (Seriation) und multidirektionaler Methoden (Korrespondenz-, Geräusch- und Faktorenanalyse).

Obwohl es heute in der Erforschung mittelalterlicher Keramik zu einem sichtlichen Aufschwung kommt, ringen wir immer noch mit einer Reihe von Problemen, von denen die größten in dem unbearbeiteten Zustand ausgemacht werden können, in dem sich eine Reihe großer archäologischer Grabungen befindet. Als außerordentlich wichtig kann ein Schritt angesehen werden, der zur Schaffung fachlicher Standards in der Beschreibung von Keramik, einschließlich einer Vereinheitlichung der Terminologie führt und der ein breiteres komparatives Studium ermöglichen würde und für angehende oder fortgeschrittene Forscher gleichzeitig ein methodisches Hilfsmittel wäre.

Die vorliegende Studie ist ein Output des Projektes NAKI II - Hochmittelalterliche Keramik als Bestandteil des beweglichen kulturellen Erbes, Projektnr. DG18P02OVV020.

Mgr. Ladislav Čapek, Ph.D., Katedra archeologie Fakulty filozofické Západočeské univerzity v Pzni, Sedláčkova 15, 30614 Plzeň, Česká republika, capekla@kar.zcu.cz,capekla.st@gmail.com 
